NBER WORKING PAPER SERIES

\author{
DO FINANCING CONSTRAINTS \\ EXPLAIN WHY INVESTMENT IS \\ CORRELATED WITH CASH FLOW?
}

Steven N. Kaplan

Luigi Zingales

Working Paper 5267

NATIONAL BUREAU OF ECONOMIC RESEARCH
1050 Massachusetts Avenue
Cambridge, MA 02138
September 1995

Benjamin Bridgman and Violet Law provided excellent research assistance. Comments from Charles Calomiris, John Cochrane, Robert Gertner, David Gross, R. Glenn Hubbard, Bengt Holmstrom, Anil Kashyap, Owen Lamont, Stewart Myers, Walter Novaes, Bruce Petersen, Raghuram Rajan, David Scharfstein, Andrei Shleifer, Jeremy Stein, Amy Sweeney, Sheridan Titman and Robert Vishny were very helpful. Seminar participants at Boston College, the Federal Reserve Board, Harvard Business School, MIT, the NBER Summer Institute, the University of Chicago, the University of Washington, the CEPR Summer Symposium in Financial Markets in Gerzensee, and the Nobel Symposium on Law and Finance also provided helpful comments. We also thank Bruce Petersen for providing a list of sample companies. This research has been supported by the Center for Research in Security Prices and by the Olin Foundation through grants to the Center for the Study of the Economy and the State. This paper is part of NBER's research programs in Corporate Finance and Public Economics. Any opinions expressed are those of the authors and not those of the National Bureau of Economic Research.

(C) 1995 by Steven N. Kaplan and Luigi Zingales. All rights reserved. Short sections of text, not to exceed two paragraphs, may be quoted without explicit permission provided that full credit, including (C) notice, is given to the source. 


\title{
DO FINANCING CONSTRAINTS \\ EXPLAIN WHY INVESTMENT IS \\ CORRELATED WITH CASH FLOW?
}

\begin{abstract}
This paper investigates the sources of the correlation between corporate cash flow and investment by undertaking an in-depth analysis of the 49 low-dividend firms identified by Fazzari, Hubbard, and Petersen (1988) as having an unusually high investment-cash flow sensitivity. We find that in only $15 \%$ of firm-years is there some question as to a firm's ability to access internal or external funds to increase investment. Strikingly, those firms that appear less financially constrained exhibit a significantly greater investment-cash flow sensitivity than firms that appear more financially constrained. We find this pattern for the entire sample period, for sub-periods, and for individual years. The results indicate that a higher sensitivity cannot be interpreted as evidence that a firm is more financially constrained. We discuss reasons and provide evidence why the opposite may be true. These findings challenge much of the existing evidence on the effects of financial constraints.
\end{abstract}

Steven N. Kaplan

Graduate School of Business

University of Chicago

1101 East 58th Street

Chicago, IL 60637

and NBER
Luigi Zingales

Graduate School of Business University of Chicago 1101 East 58th Street Chicago, IL 60637 and NBER 
"Our financial position is sound ... Most of the company's funds are generated by operations and these funds grew at an average annual rate of $29 \%$ lover the past 3 years]. Throughout the company's history this self-financing concept has not been a constraint on the company's growth. With recent growth restrained by depressed economic conditions, the company's net cash position has grown substantially." Hewlett-Packard 1982 Annual Report

1.

Introduction

There is a large finance and macroeconomic literature that studies the relation between corporate investment and cash flow to test for the presence and importance of financial constraints. Beginning with "Financing Constraints and Corporate Investment," by Fazzari, Hubbard and Petersen (1988), henceforth FHP, these studies divide a sample of firms according to an a priori measure of financial constraints and compare the investment-cash flow sensitivities of the different subsamples.' The finding of a greater investment-cash flow sensitivity for the firms more likely to be constrained is typically interpreted as evidence of a large wedge between the internal and external cost of funds. According to the theory, this wedge, which is generally attributed to information problems in external capital markets, leads to underinvestment by firms that lack internal funds. Some authors also have argued (e.g., Bernanke et al., 1994) that this wedge widens during recessions, worsening the underinvestment problem and exacerbating business cycle movements. These findings and the related interpretation has shaped the view of economists and policy makers on the functioning of extemal capital markets as well as on the effects of monetary and fiscal policy.

Despite the size and policy-relevance of this literature, the fundamental assumptions underlying it have been largely unexplored. While work subsequent to FHP has found that firms identified to be financially constrained according to an a priori criterion exhibit a greater sensitivity of investment to cash flow, no paper (of which we are aware) has verified directly whether a higher investment-cash flow sensitivity is related to financing problems and, if it is, in what way.

This paper investigates the sources of the investment-cash flow sensitivity by undertaking an in-depth analysis of a sample of firms exhibiting an unusually high sensitivity of

I For example, see Hoshi, Kashyap, and Scharfstein (1991), Whited (1992), Calomiris and Hubbard (forthcoming). 
investment to cash flow. These firms are the 49 low dividend firms that FHP (1988) identify as financially constrained according to the investment-cash flow criterion.

By using detailed and previously unexplored data sources, we try to determine the availability of and the demand for funds for each of the sample firms. We examine each firm's annual report or 10-K for each sample year, and we read management's discussion of liquidity that describes the firm's future needs for funds and the sources it plans to use to meet those needs. We integrate this information with quantitative data and with public news to derive as complete a picture as possible of the availability of internal and external funds for each firm as well as each firm's demand for funds. On this basis, we rank the extent to which the sample firms are financially constrained each year. We use the firm-year classifications to group the sample firms over seven or eight-year sub-periods, and over the entire sample period. Finally, we compare investment-cash flow sensitivities across the different groups of firms.

Surprisingly, we find that in only $15 \%$ of firm-years is there some question as to the ability of the firms to access internal or external funds to increase investment. In $85 \%$ of firmyears, the firms could have increased their investment - in many cases, substantially - if they had so chosen. In fact, almost $40 \%$ of the sample firms -- including Hewlett-Packard -- could have increased their investment in every year of the sample period. Our partially qualitative measures of financial constraints are strongly corroborated by quantitative data on debt to total capital, interest coverage, the presence of restrictions on dividends, and financial slack (the level of cash and unused line of credit relative to investment)

More strikingly, those firms classified as less financially constrained exhibit a significantly greater investment-cash flow sensitivity than those firms classified as more financially constrained. We find this pattern for the entire sample period, for sub-periods, and for individual years. This pattern is also robust to different criteria to divide constrained and unconstrained firms. For example, firms with heal thy interest coverage in every sample year or in every sub-period year have investment-cash flow sensitivities twice as large as the remaining firms in the sample. 
Our results raise the obvious question of what is the source of the investment-cash flow sensitivity? Why do companies that face difficulties in accessing external capital markets show a lower sensitivity? At the same time, why do companies facing no obvious constraint on their ability to invest exhibit a particularly high sensitivity of investment to cash flow? The remainder of the paper considers alternative explanations for these sensitivities.

We find evidence that the high overall sensitivity of our sample (FHP's low dividend payout firms) relative to FHP's higher dividend payout firms can be explained by cash flow acting as a proxy for investment opportunities. However, this does not explain our cross-sectional results that the least constrained firms have the highest sensitivities.

We, then, consider several plausible explanations for why the investment-cash flow sensitivity does not increase monotonically with financial constraints. We find evidence consistent with these explanations as to why the most constrained firms in our sample have the lowest sensitivities.

The results, however, do not provide a complete understanding of why the investmentcash flow sensitivity is so high for our unconstrained firms. The high investment-cash flow sensitivities appear to be driven by managers choosing to rely primarily on internal cash flow to invest despite the availability of additional low cost funds. The most financially successful and least constrained firms in our sample appear to follow this rule and, therefore, exhibit a high investment-cash flow sensitivity. The key question - that we cannot answer with certainty -- is whether those least constrained firms are unconstrained in an absolute sense. The answer to this question leads to very different interpretations.

Independent of which of the alternative interpretations holds, our results have two primary implications. First, the results indicate that a greater investment-cash flow sensitivity does not provide evidence of a larger differential cost between internal and external finance. This calls into question previous work that relies on this sensitivity as evidence for the importance of financial constraints.

Second, our results suggest that policies designed to make credit more available in 
recessions will not lead to increased investment by firms with the highest investment-cash flow sensitivity. These firms reduce their investment in response to poor cash flow despite the current availability of internal and external funds.

The paper proceeds as follows. Section 2 presents the theoretical framework. Section 3 describes the sample. Section 4 explains the criteria used to identify the extent to which firms are financially constrained. Section 5 reports the investment-cash flow regression results. Section 6 discusses the results and considers altemative explanations for them. Section 7 discusses the implications of our findings and concludes.

Theoretical Framework

$2.1 \quad$ Competing Hypotheses

The neoclassical theory of investment in the presence of adjustment costs (Summers, 1981 and Hayashi, 1982) derives a formal relationship between a firm's investment and the ratio of asset market value to replacement cost (better known as Tobin's $Q$ ). More importantly, the $Q$ theory establishes that a firm's marginal $Q$ should be the only determinant of investment. In other words, investment should not be sensitive to a firm's cash flow after controlling for marginal $Q$.

As noted earlier, there is a well-established literature that indicates that investment is sensitive to cash flow even after controlling for $Q$. The possible explanations for this phenomenon can be divided in two groups. First, researchers have focused on the shortcomings of measured $Q$ (which is effectively average $Q$ ) as a sufficient statistic for a firm's investment opportunities. According to this view, internal cash flow is a proxy for investment opportunities not captured by measured $Q$. Although investment is not truly affected by cash flow, investment will be correlated with it.

Altematively, many researchers have questioned the strongest assumption underlying all neoclassical models: the existence of perfect capital markets. According to this second approach, a firm may find external funds either unavailable or prohibitively expensive and, in the absence of internal funds, reduce investment. 
The supply of funds to firms may be imperfect for two primary reasons: hidden information problems and agency problems. Hidden information models -- e.g., Myers and Majluf (1984) and Greenwald, Stiglitz, and Weiss (1984) -- assume that managers act in the interest of shareholders, but firms face a high cost of external funds because investors are unsure about firm quality. Firms that lack internal funds, therefore, will be unable or will find it too expensive to raise extemally the capital necessary to undertake all positive present value investments (that they would undertake if financial markets were perfect). Such financially constrained firms, therefore, underinvest.

Agency models -- e.g., Jensen and Meckling (1976), Grossman and Hart (1982), Jensen (1986), Stulz (1990), and Hart and Moore (1990) - emphasize the conflict of interest between managers and shareholders. These models assume that managers derive private benefits from investments and, therefore, will invest more when internal cash flow permits. As a result, unconstrained firms overinvest while constrained firms invest optimally.

Both the hidden information and agency theories predict a "pecking order" in financing choices: firms prefer internal finance and if external finance is required, they issue the safest security first (Myers, 1984). Both theories, therefore, predict a higher sensitivity of investment to cash flow for financially constrained firms. These models tend to share the characteristic that more constrained firms are those that face a higher shadow cost of external funds today (although not necessarily in the future).

FHP was the first paper to attempt to distinguish between the mismeasured-Q theory and the imperfect capital market theories. Their innovation was to use an a priori proxy for the probability a firm is financially constrained as an instrument to sort out the effects of mismeasured$Q$ from the effects of imperfect capital markets. They interpret their finding of a larger sensitivity of investment to cash flow in firms a priori more likely to be financially constrained as evidence in favor of the imperfect capital market explanation.

With the exception of Blanchard et al. (1994), the subsequent literature has followed FHP by splitting firms according to an a priori proxy for financial constraints in order to isolate the 
effect of imperfect capital markets. Blanchard et al. (1994) attempt to distinguish between the two imperfect capital market theories by studying a small sample of firms that received a large cash windfall -- generally a legal award -- without experiencing any change in marginal $Q$. Their analysis of the use of the cash windfall suggests that agency problems are more important than hidden information problems for those firms.

Our research design is structured to shed light on the extent to which the investmentcash flow sensitivity is linked to imperfections in the supply of extemal funds

\subsection{What Is the Definition of Financial Constraints?}

In order to determine whether a firm is financially constrained we need to define what being financially constrained means. Unfortunately, the existing literature is somewhat unclear about this point. To guide our empirical analysis we adopt the following approach.

We define a firm as being financially constrained if the cost or availability of external funds precludes the company from making an investment it would have chosen to make had intemal funds been available. In other words, there is a wedge between the intemal and extemal costs of funds. Our classification scheme is designed to distinguish relative differences in the degree to which firms are financially constrained. For example, we will classify a company that is restricted by its lenders from paying dividends and increasing debt as more constrained than a company sitting on large cash reserves with no debt. In general, our unconstrained or less constrained firms are those firms with relatively large amounts of liquid assets and net worth.

Although our classification scheme cannot explicitly determine whether firms face a spread between the cost of internal and external finance, our scheme certainly captures cross sectional differences in the magnitude of this spread. The theories of imperfect capital markets definition imply that the more financially constrained firms will exhibit greater investment-cash flow sensitivities. 
In this paper, we analyze the sample of 49 low-dividend paying firms in FHP (1988).

FHP divide all manufacturing firms in the Value Line data base with uninterrupted data from 1969 to 1984 into three classes based on dividend payout policy. Their 49 Class 1 firms (which we analyze) have a dividend payout ratio of less than $10 \%$ in at least ten of the fifteen years. In contrast, FHP classify 39 firms that have a dividend payout ratio between $10 \%$ and $20 \%$ as Class 2 firms, and all 334 other firms in their sample as Class 3 firms. FHP argue that the Class 1 firms are more likely, a priori, to have been financially constrained. In their analysis, they find that the Class I firms have an investment-cash flow sensitivity that is significantly greater than that for firms that pay higher dividends.

We choose this sample for three reasons. First, these firms exhibit a strong relation between investment and cash flow. Second, FHP argue strongly that these firms are financially constrained, most likely because of information problems. Because FHP (1988) can legitimately be considered the parent of all papers in this literature, there can be no disagreement that we have adversely selected our sample. Finally, given the high cost of our research design, the number of firms is manageable.

We follow this sample for the same fifteen years, 1970 to 1984 , studied by FHP. For each firm, we collected data from several sources. First, we collected letters to shareholders, management discussions of operations and liquidity (when available), financial statements, and the notes to those statements from the annual report or 10-K for each firm-year. We also obtained Wall Street Journal Index entries over the 15 year sample period. ${ }^{2}$ We obtained standard accounting variables from COMPUSTAT except those for Coleco which we obtained from Coleco's annual reports. Because FHP obtained their data from Value Line not COMPUSTAT, our data are not precisely the same as theirs.

We measure investment or capital expenditures using COMPUSTAT item 128 . We

\footnotetext{
${ }^{2}$ Fiscal years ending before June 15 are assigned to the previous calendar year; fiscal years ending after June 15 are assigned to the current calendar year.
} 
measure cash flow as the sum of earnings before extraordinary items (item 18) and depreciation

(item 14). We deflate investment and cash flow by capital which we measure as net property,

plant, and equipment (item 8) at the beginning of the fiscal year. This measure of capital differs

slightly from the replacement cost measure employed by FHP.

We measure average Tobin's $Q$ as the market value of assets divided by the book value of assets (item 6) where the market value of assets equals the book value of assets plus the market value of common equity less the sum of the book value of common equity (item 60 ) and balance sheet deferred taxes (item 74). We calculate $Q$ at the beginning of a firm's fiscal year. ${ }^{3}$

In table l, we compare the basic regression results for our sample with those reported in table 4 of FHP. These regressions regress investment on cash flow and $Q$, and control for fixed firm and year effects. Our results are qualitatively similar to those reported by FHP, although they differ slightly in some details." For each of the three time periods, our coefficients on cash flow are lower than those reported by FHP. Those differences, however, appear to be only marginally significant, if at all. At the same time, our coefficients for $Q$ are significantly greater than those reported by FHP.

We attribute the differences between our results and those of FHP to the different definitions of $Q$. When we exclude $Q$ from our regressions, we obtain coefficients on cash flow that exceed those in FHP except for the $1970-75$ period where our coefficient is insignificantly smaller. Because the FHP measure is constructed with an average stock price rather than an endof-year stock price, we suspect our measure of $Q$ provides better information about investment opportunities. The FHP measure will not distinguish between a firm whose stock price declines

\footnotetext{
' Our measure differs from FHP in two ways. First, FHP compute $Q$ based on replacement costs, while we simply use a market-to-book ratio. The results in Perfect and Wise (1994) indicate that the improvements obtained from the more involved computation of $Q$ are fairly limited, particularly when regressions are estimated with firm fixed effects. Second, FHP use the average market value of equity in the fourth quarter while we use the actual market value of equity at fiscal year end.

- We use 719 observations, not 735 , because firms switched fiscal years ( 3 firm-years), firms did not file financial statements with the SEC (6 firm-years), and firms did not have an available stock price (7 firm-years).
} 
from 20 to 10 and a firm whose stock price increases from 10 to 20 in the last quarter.

4. Classification Scheme

4.1 Description

The SEC requires companies that are listed on a stock exchange, have more than 500 shareholders, and more than $\$ 5$ million in assets to file an annual report or 10-K that contains the basic financial statements and their notes, as well as all material information regarding a company's business and financial condition. The annual reports are generally introduced by a letter to shareholders from the chief executive officer (CEO). This letter usually describes the major events of the previous fiscal year and the major challenges or projects planned for the year(s) ahead.

In 1977, the SEC strengthened these reporting requirements by adopting Regulation S-

$\mathrm{K}$, which requires firms to discuss explicitly their liquidity, capital resources, and results of operations. This section is usually titled management's discussion of operations. Item 303 of Regulation S-K states:

(1) Liquidity. Identify any known trends or any known demands, commitments, events, or uncertainties that will result in ... the registrant's liquidity increasing or decreasing in any material way. If a material deficiency is identified, indicate the course of action that the registrant has taken or proposes to take to remedy the deficiency. Also identify and separately describe internal and external sources of liquidity, and briefly discuss any material unused sources of liquid assets...

(2) Capital Resources. (1) Describe the registrant's material commitments for capital expenditures as of the end of the Iatest fiscal period, and indicate the general purpose of such commitments and the anticipated source of funds needed to fulfill such commitments ... (ii) Describe any known material trends, favorable or unfavorable in the registrant's capital resources. Indicate any expected material changes in the mix and the relative cost of such resources.

Instructions: 5. The term "liquidity" ... refers to the ability of an enterprise to generate adequate amounts of cash to meet the enterprise's needs for cash. ... Liquidity shall generally be discussed on both a long-term and short-term basis.

In short, Regulation S-K explicitly requires firms to disclose whether or not they are having

difficulty in financing their investments. Consistent with the timing of the new SEC regulations,

s See SEC 63031 in Murray et al. (1993). 
the post-1977 annual report information for our sample firms tends to be somewhat more detailed than the information for earlier years. To the extent that our classification scheme has errors, those errors should be smaller for years after 1977.

We use the qualitative information in the annual reports, together with quantitative information in the companies' financial statements and notes, to classify each firm-year into one of five groups.

The first group contains firms that we deem to be definitely not financially constrained in that year. We refer to these firm-years as not financially constrained (NFC). We place a firmyear in the NFC group if the firm initiated or increased cash dividends, repurchased stock, or explicitly indicated in its annual report that the firm had more liquidity than it would need for investment in the foreseeable future. ${ }^{6}$ We also were more likely to label a firm-year NFC if the firm had a large cash position (relative to investment) or if the firm's lenders did not restrict the firm from making large dividend payments (relative to investment). NFC firm-years, therefore, tend to include financially healthy companies with low debt and high cash. In NFC firm-years, therefore, we find no evidence that these firms could not have invested appreciably more if their managers had so chosen. In NFC firm-years, NFC firms also appear to have large amounts of internal funds and collateralizable resources relative to the amount of funds required.

The second group includes firm-years that we label likely not to be financially constrained (LNFC). In LNFC firm-years, the firms are healthy financially and do not give any indication of being liquidity constrained. These firms also tend to have sizeable cash reserves, unused lines of credit, and healthy interest coverage. LNFC firm-years are distinguished from NFC firm-years by an absence of an explicit statement of excess liquidity and by the magnitude of the measures of liquidity. Again, in LNFC firm-years, we find no evidence that these firms could not have invested more if their managers had so chosen. It is worth pointing out that despite the

"For example, Plantronics' 1971 annual report states: "We ended the year in an exceptionally strong financial strong condition for a company of our size. During the year we paid off all long-term debt, and our cash and cash-equivalent assets have throughout the year, exceeded all current liabilities." 
statement in the introduction, we classify Hewlett-Packard as LNFC for five firm-years in the 1970 s.

The third group includes firm-years we found difficult to classify either as financially constrained or as unconstrained. We call these firm-years possibly financially constrained (PFC). In PFC firm-years, firms do not report any clear signs of financial constraints, but they do not look particularly liquid either. Frequently these firms face an adverse product market environment, but are not explicitly strapped for cash. This category also includes firm-years which provide contradictory indications of their financial situation. For example, this might include a company that increases its dividend, but laments its lack of financial resources in the letter to shareholders.

The fourth group contains all firm-years in which firms are likely to be financially constrained (LFC). This group includes firms that mention having difficulties in obtaining financing. For example, we include firm-years in which firms postpone an equity or convertible debt offering for "adverse market conditions," or claim that they need equity capital but are waiting for "improved market conditions." Generally these companies are prevented from paying dividends and have little or no cash available. Companies that cut dividends also are more likely to fall in this category, unless other adverse factors assign them to the fifth group.

The last group includes all firm-years in which firms are undoubtedly financially constrained (FC). In these firm years, these companies are in violation of debt covenants, have been cut out of their usual source of credit, are renegotiating debt payments, or declare that they are forced to reduce investments because of liquidity problems.

Overall, we are confident that our classification scheme captures relative differences in the extent to which the sample firms have access to funds in a given year. Our reading of the financial statements and management discussions strongly indicates that the NFC (and LNFC) firms could have invested more (often substantially more) in that year had they so chosen. In other words, there is no sense in which the NFC (and LNFC) firms were contemporaneously constrained. However, we recognize the possibility that even NFC (or LNFC) firms behaved as if they were constrained for fear of being constrained in the future. 
Our classification scheme is subject to two potential criticisms: (1) managers may not report truthfully; and (ii) we may not classify firm-years accurately. We do not view management misreporting as a serious problem for several reasons. First, managers are held liable not only for disclosing false information, but also for not disclosing material information. This is particularly true after 1977 when Regulation S-K is in effect.' Second, we read annual reports over a fifteen year period. While a firm may be able to misreport in any given firm-year, it seems unlikely that a firm can misreport every year. Third, we do not rely exclusively on the management discussions, but also read the financial statements carefully. Finally, any management reluctance to report negative information should bias our results against finding financially constrained companies and differences across groups. To the extent we find some companies to be financially constrained, we can be certain that they are indeed constrained. Similarly, to the extent we find differences across groups, we can be confident that these differences represent a lower, and not an upper, bound.

\subsection{Classification Results}

Table 2 summarizes our classification of firm-years. We classify $54.5 \%$ of firm-years as not (NFC) and $30.9 \%$ of firm-years as likely not financially constrained (LNFC) for a total of $85.3 \%$ of firm years in which we find no evidence of financial constraints that restrict investment. We classify $7.3 \%$ of firm-years as possibly constrained, $4.8 \%$ as likely constrained, and $2.6 \%$ as definitely constrained for a total of only $14.7 \%$ years in which there is some possibility of financial constraint. The fraction of firms that are at least possibly constrained, however, varies a fair amount over time, with more firms being potentially constrained in the early part of the sample (when these firms were smaller), and particularly around the 1974-75 recession. This time pattern is consistent with the results in FHP (1988) and in table 1 that investment-cash flow sensitivities decline over the sample period. (In the Appendix, we report the year-by-year classifications for all 49 firms.)

For example, the SEC took action against Caterpillar, Inc. for not reporting that a large increase in Caterpillar's 1989 net income was caused by a hyperinflation in Brazil. 
We consider the accuracy of our classification scheme by reporting quantitative measures of operational and financial health across our five classifications in Table 3. In panel A, median cash flow, net cash flow (cash flow less investment), and Tobin's $Q$ decline monotonically across the five categories. For example, the median level of net cash flow for NFC firms is $11 \%$ of capital (net property plant and equipment) while the median level of net cash flow for FC firms is almost $-20 \%$. This suggests that NFC firms could have increased their investment without tapping external sources of capital. The mean level of acquisitions (as a fraction of capital) is substantially higher for firms in the first two groups (NFC and LNFC) than firms in the other three groups. Acquisitions are completely absent in FC firm-years. Finally, NFC and LNFC firm-years experience more sales growth than firm-years in which firms are at least potentially constrained. In FC firm-years, firms do not experience any nominal growth.

Panel B reports summary statistics on firm financial status. Interest coverage -- earnings before interest, taxes, and depreciation or EBITD (COMPUSTAT item 13) to interest expense (item 15) -- declines monotonically across our classifications. ${ }^{9}$ Debt to total capital also decreases monotonically -- debt is the sum of the book value of short-term and long-term debt (items 9 and 34), while total capital is the sum of debt, the book value of preferred stock, and the book value of common equity. It is worth pointing out that the NFC firm-years have a large median interest coverage of almost 8 times while the LNFC firm-years have a median coverage of almost 6 . In contrast, LFC firm-years have a median coverage of less than 3 times and FC firm-years have a median coverage that barely exceeds 1 .

The notes to the financial statements typically state whether a firm's debt covenants - if the firm has any debt - place any restrictions on a firm's ability to pay dividends. We interpret a firm as being more financially constrained the greater the restrictions placed on dividend payments

\footnotetext{
- We calculate acquisitions as the value of businesses or companies acquired in a given firm-year as a fraction of beginning of year capital. We value purchase acquisitions using information in the statement of changes. We value pooling acquisitions using the notes to financial statements.

"We set interest coverage to 100 if coverage exceeds 100 or interest expense is negative. We set interest coverage to 0 if EBITD is negative.
} 
by covenants. Table 3 reports that the fraction of firm-years in which debt covenants forbid the payment of dividends increases monotonically across our classifications. NFC firm-years are restricted $6.1 \%$ of the time while LFC and FC firms are restricted more than $68 \%$ of the time. In the majority of firm-years, the notes to financial statements also report exactly how much of retained earnings are free for dividend payments under the strictest debt covenants. ${ }^{10}$ Panel $B$ of table 3 indicates that this amount falls monotonically across our five groups. In NFC firm-years, the median amount of earnings free for dividends equals $20.8 \%$ of beginning of year capital and almost $58 \%$ of the year's investment. In other words, the median NFC firm could have paid out a dividend equal to $58 \%$ of its capital expenditures without the permission of existing lenders.

Finally, cash (COMPUSTAT item 1), unused line of credit, and slack (the sum of cash and the unused line of credit) all decline monotonically across our classifications. Slack is important because it provides a measure of the amount of funds or liquidity immediately available to a firm at year-end. Slack may overstate true liquidity somewhat because firms were commonly required to maintain compensating balances. That qualification not withstanding, the median slack in NFC firm-years is $72.5 \%$ of beginning of year capital and $191 \%$ of the year's investment. For LNFC firm-years, the analogous amounts are $42 \%$ and $119 \%$.

As an additional check, we estimate ordered logit models of the probability a firm falls in one of the five categories -- with NFC being the lowest state and FC the highest. The results are presented in table 4 . The likelihood of being classified as financially constrained is significantly greater in firms with higher debt to total capital, higher $Q$, and for whom dividend payments are forbidden; the likelihood is significantly lower in firms with high cash flow, high cash, high dividends paid, high retained earnings free for dividends, and with any unused line of credit at all. All the coefficients are statistically significant at the $1 \%$ level, and all the coefficients except perhaps the one on $Q$ have the expected sign. $Q$ has a positive impact on the probability of being

I" This information is not reported in years that a firm has no debt as well as some of the earlier firm years. 
financially constrained. This is true despite the univariate result in table 3 that $Q$ decreases with firm financial health. The likely explanation for this result is Q's partial correlation with cash flow In the absence of cash flow, the coefficient on $Q$ becomes negative. One way to interpret this result is that conditional on having a low cash flow, we classify a firm as more likely to be constrained if it has more investment opportunities (high Q).

Overall, we feel that the monotonic parterns of most of the operating and financial variables in table 3 and the results in table 4 provide a strong quantitative validation of the accuracy of our classification scheme.

\subsection{Overall Financial Status}

In order to analyze investment-cash flow sensitivities over fifteen years, we aggregate each firm's annual financial status into an overall measure of financial status. We refer to this as sample financial status (rather than firm-year financial status). We distinguish firms that were never financially constrained from those that were. We do this to account for the likelihood that firms which become constrained will behave as if they are constrained.

Our classification provides a great deal of variation. Nineteen firms are never constrained -- they were classified as NFC or LNFC in all 15 sample years. These firms never showed any sign of being financially constrained over the entire period. Eight firms are possibly constrained. These firms were possibly constrained in at least one year and not constrained (NFC or LN FC) in all the rest. Finally, 22 firms are likely constrained. These firms were classified as LFC or FC in at least one sample year.

We also aggregate annual financial status into overall status over two sub-periods: 1970 to 1977 and 1978 to 1984 . We classify firms according to whether they were likely constrained, possibly constrained, or not constrained within each sub-period. We do this for four reasons. First, the classification over the entire sample period will classify a firm as financially constrained even if that firm was constrained in only one of the fifteen sample years. By measuring financial status over sub-periods, we increase the precision of our classifications. Second, the research 
design in FHP biases the sample toward companies that were small in 1970, but were established enough by 1984 to be included in the Value Line data set. Therefore, a firm in the earlier part of the sample is conceivably different from the same firm later on. Third, as noted earlier, the information contained in the management discussions and footnotes of annual reports improves after 1977. Therefore, we believe that the possibility that we have misclassified firms in the second sub-period declines substantially. Finally, as noted earlier, FHP (1988) report that the sensitivity of investment to cash flow is particularly strong in the first half of the sample, when these firms were smaller and more likely to have been financially constrained.

5. Regression Results

Armed with a direct measure of a firm's financially constrained status, we can now test if financing constraints explain cross sectional differences in investment-cash flow sensitivities.

\subsection{Basic Specification}

We estimate regressions for all firms and by firm sample financial status. We use the regression specifications presented in table 1 over the entire sample period. Table 5 presents our basic results. Firms classified as never constrained (NFC or LNFC in every sample year) exhibit the highest investment-cash flow sensitivity $(0.702)$, exceeding that for the entire sample $(0.395)$, for firms that were likely constrained $(0.340)$, and for firms that were possibly constrained $(0.180)$. The coefficient for the never constrained firms is economically and statistically greater than the coefficients for the other firms.

As we noted earlier, we are not entirely comfortable with the classification of possibly constrained firms. If managers tend to under-report negative information about their firm's financial condition, then it would be appropriate to group the eight possibly constrained firms with the likely constrained firms. Not surprisingly, this grouping lowers the coefficient on constrained firms to 0.250 , and widens the gap between constrained firms and unconstrained firms. It is worth pointing out that the 0.25 sensitivity is insignificantly different from that of the high-dividend FHP 
class 3 firms and actually smaller than that of the FHP class 2 firms.

Alternatively, it is possible that we have been excessively conservative and have classified firms as possibly constrained when they were, in fact, unconstrained. Accordingly, we also estimate a regression in which we group the possibly constrained firms with the never constrained firms. While this lowers the investment-cash flow sensitivity substantially (to 0.439 ), it does not alter the basic result that unconstrained firms exhibit a greater investment-cash flow sensitivity

In tables 6 and 7, we repeat our basic analysis, but break the sample into two subperiods: 1970 to 1977 and 1978 to 1984 . Table 6 treats a firm in the $1970-1977$ sub-period as different from the same firm in the 1978-1984 sub-period. The regressions presented in table 6 , therefore, include 98 firm-sub-periods (with firm-sub-period fixed effects). Again, the coefficients sharply reject the hypothesis that financially constrained firms have greater investment-cash flow sensitivities. In table 6, firms that are not constrained in a sub-period have an investment-cash sensitivity of 0.680 . This is significantly greater than the sensitivity of 0.436 for all firm subperiods and greater than the sensitivity of firms that are possibly constrained (at 0.259 ) or likely constrained (at 0.274$)$

Table 6 also presents regression results for the fifteen firm-sub-periods for which we classify the firm as NFC in every year in the sub-period." Ten of the fifteen sub-periods fall in the 1978-1984 period during which even FHP argue the sample firms were less likely to be constrained. Strikingly, the investment-cash flow sensitivity for these fifteen sub-periods of 0.779 exceeds any of the coefficients for any group of firms we present in tables 5 and 6.

Based on our classification scheme and the quantitative support for that scheme in tables 3 and 4, we find it impossible to argue that these firms were unable to invest more during any of these 15 sub-periods. We also find it difficult to argue that these firms faced a particularly high cost of external finance. Hewlett-Packard, for example, is included among these 15 sub-

\footnotetext{
"We do not create this classification over the entire sample period because we classify only two firms as NFC in all fifteen years.
} 
periods in 1978-1984 (although not in 1970-1977). And Hewlett-Packard has an investment-cash flow sensitivity of 0.97 over the $1978-1984$ sub-period, 0.92 over the 1970-1977 sub-period, and 1.15 over the entire sample period. It is worth stressing that the 15 firms that are NFC in every sub-period year have financial characteristics that are similar to those of FHP's Class 3 firms that pay high dividends and have a low investment-cash flow sensitivity (0.23) For example, the NFC firms and FHP's Class 3 firms have interest coverage ratios that are economically and statistically indistinguishable. It seems difficult to understand how one set of firms can be constrained while the other is not.

Table 7 presents results for each of the two sub-periods separately. Again, we find no evidence that financial constraints explain the sensitivity of investment to cash flow. In both subperiods, the firms that we classify as NFC every year and as never constrained have a significantly higher investment-cash flow sensitivity than the other groups of firms. Furthermore, in the 19781984 period where we are more certain of our classifications, the sensitivity declines monotonically with the extent to which we classify firms as constrained.

\subsection{Alternative Definitions of Financially Constrained Status}

Given the results in the previous section, some readers may be concerned that we have misclassified firms by using qualitative data or by basing firm financial status on an overly long -seven to fifteen year - period. To address these concerns, we report the results of grouping firms based on quantitative / objective data and based on annual financial status.

In regressions (1) - (3) of table 8, we present estimates of the investment-cash flow sensitivities for (I) the $25 \%$ of sample firms whose interest coverage never drops below 2.5 and (ii) firms whose dividends are never restricted over the entire sample period. Given the two severe recessions over the sample period, these criteria should identify firms that were relatively financially healthy. The investment-cash flow sensitivity for the $13 \mathrm{firms}$ whose coverage never drops below 2.5 is significantly greater at 0.673 than the sensitivity of 0.395 for the entire sample. The investment-cash flow sensitivity for the 17 firms whose dividends are never restricted at 0.435 
also exceeds the sensitivity for the entire sample, although not significantly.

In regressions (4) - (6), we split the sample into sub-periods as we did in table 6. We present estimates of the investment-cash flow sensitivities for (I) the $25 \%$ of firm-sub-periods whose interest coverage never drops below 4.5 in the sub-period; and (ii) firms whose dividends are never restricted over the sub-period. The patterns are qualitatively similar and quantitatively stronger than those for the entire sample period. The investment-cash flow sensitivity for the 21 firms whose coverage never drops below 4.5 in a sub-period is a remarkably high 0.801 . We should point out that the median interest coverage for firms rated BBB by Standard \& Poor's in 1979-1981 was 3.82; the median for firms rated $A$ was 6.56 . In other words, these firms are not likely to have faced particularly high costs of external finance in absolute terms in the sub-periods. More importantly, in relative terms, it is virtually certain that they faced lower costs of external finance than the other firms in our sample, and, yet, show a higher investment-cash flow sensitivity

In table 9, we present differential estimates of the investment-cash flow sensitivities by interacting cash flow with annual measures of financial constraint status. ${ }^{12}$ First, we interact cash flow with dummy variables for our annual classifications of financial constraint status. The base or uninteracted coefficient corresponds to the NFC firm-years -- firm-years we classify as not financially constrained. The regression in column (1) interacts the end-of-the-year classification while the regression in column (2) interacts the beginning-of-year classification with that year's cash flow. We report both because we classify firms using the end-of-year financial statements. The results are, again, qualitatively identical to the results in the previous sections. The investment-cash flow sensitivity declines with our qualitative measure of financial constraint. In regression (3), we interact cash flow with a dummy variable that equals one if debt covenants restrict the firm from paying dividends in a firm-year. It seems reasonable to assume that such firms are more financially constrained than firms not restricted from paying dividends.

\footnotetext{
12 Our results are qualitatively identical when we also include dummy variables for the intercept term.
} 
Again, we find that the investment-cash flow sensitivity is significantly lower, not higher, for firms restricted from paying dividends. We obtain virtually identical results (which, therefore, we do not report) when we use the lagged value of the dummy variable.

Finally, in regression (4) we interact cash flow with a dummy variable that equals one for firm-years in which our slack variable - the sum of cash and unused lines of credit as a fraction of capital -- is in the lowest quartile of firm-years. The low slack cutoff is $28 \%$ of beginning-ofyear capital (net property, plant, and equipment). Our results are not sensitive to this cutoff. It seems reasonable to assume that firms with less slack are more financially constrained than firms with more slack. Again, we find that the investment-cash flow sensitivity is lower, not higher, for firms with low slack. Again, we obtain virtually identical results when we use the lagged value of the dummy variable.

Overall, then, we observe the same pattern as in the previous section using quantitative measures of financial constraints and using our qualitative measure of financial constraints over shorter periods.

\subsection{Alternative Specifications.}

We considered, but do not report, a number of alternative specifications of our basic regressions. (1) We removed $Q$ as an independent variable leaving cash flow as the only independent variable. (2) We added the ratio of sales to capital as an independent variable with $Q$ and cash flow to capital. (3) We included two lags of cash flow and $Q$ as independent variables. (4) To reduce the influence of outliers, we: (I) winsorized investment, cash flow, and Q; (ii) deflated investment and cash flow by total assets rather than capital; and (iii) eliminated observations with negative cash flow. (5) We ran regressions for each firm individually. (6) We checked whether the results hold if we exclude any particular firm from the sample. Our results are qualitatively and statistically identical under all of these alternatives. 
Our results indicate that a high sensitivity of investment to cash flow is not associated with financially constrained firms. This contrasts with the results in FHP (1988) and many subsequent papers. Firms that appear less constrained exhibit a higher sensitivity than those that manifest clear signs of being constrained. Given the controversial nature of our findings, it is important to explore whether our results capture general features of the relationship between corporate investment and cash flow or, instead, are specific to the sample or the techniques we use.

\subsection{Mismeasurement of financial constraint status?}

The simplest (and easiest to dismiss) explanation of our results is that we rely on highly subjective or arbitrary indicators of financial constraints, while the rest of the literature uses more objective criteria. We regard this criticism as totally unfounded for at least three reasons.

First, we obtain qualitatively similar results using a series of objective criteria, like minimum coverage and amount of earnings unrestricted for dividends.

Second, our relative ranking is not at all arbitrary. There is no doubt that a firm like Hewlett Packard (see quote at the beginning of the paper) is less constrained than a firm like Cordis in 1975:
"In order to conserve capital, construction in the proposed plant in Miami Lakes was suspended in December. It is anticipated that work will resume as soon as suitable financing is available." 1975 Annual Report.

Moreover, all the quantitative indicators reported in Table 3 support our classification scheme.

Finally, the theoretical foundations for some of the criteria used in previous work are arguably more arbitrary than our classification scheme. The most popular criterion (FHP, Bond and Meghir [1994], Calomiris and Hubbard [1995], and Kashyap, Hubbard and Withed [1995]) is based on dividend payout. Unfortunately, corporate finance theory suggests that firms should not pay any dividends at all in the presence of taxes. Furthermore, most of the existing theories of why dividends are paid (Bhattacharya [1979], Miller and Rock [1985]), explain their temporal pattern, but are silent on their average level. Although it is reasonable to assume that firms that pay more 
dividends are less likely to be constrained, at the current stage of the theoretical literature this assumption is debatable.

\subsection{Mismeasurement of investment?}

Although we use the definition of investment that is standard in the literature

(COMPUSTAT variable 128), it is possible that this definition is incorrect. For example, a number of the firms in our sample have large research and development programs, and a few of the sample firms make acquisitions (although FHP note that they eliminated firms from their sample that made large acquisitions).

We account for these possibilities by estimating our basic regressions in four different ways. First, we use a different definition of capital expenditures -- COMPUSTAT variable 30 that includes increases in property, plant, and equipment from acquisitions that use purchase accounting. Second, we calculate investment as the change in net property, plant, and equipment. Third, we calculate investment as the change in net property, plant, and equipment adding back depreciation. Fourth, we define investment as the sum of capital expenditures and research and development. All four adjustments yield results that are qualitatively and statistically identical to our basic results.

In conclusion, there is little doubt that the less constrained firms in our sample have a higher investment-cash flow sensitivity. We have established, therefore, that it is inappropriate in our sample to use a differential investment-cash flow sensitivity as evidence that a firm or group of firms is financially constrained. The question, then, becomes how general this result is

\subsection{Cash flow as a proxy for investment opportunities?}

A different explanation for our results is that our sorting criterion is correlated with the mismeasurement of $Q$. This criticism is not specific to our paper, but was in fact first raised in the discussion of FHP by Poterba (1988) and explored further in Gilchrist and Himmelberg (1994). Splitting a sample to disentangle the effects of mismeasurement of $Q$ from the effects of liquidity 
constraints is valid only if the sorting criterion is correlated with the true unobservable variable (financial constraint status), but uncorrelated with the error (the extent to which cash flow is a proxy for the mismeasurement of $Q$ ). This, of course, is the standard requirement for a valid instrumental variable. We believe our research design is less subject to this criticism because our classification scheme, based on direct observation, will more accurately measure the unobservable variable. Nevertheless, it is important to explore this issue empirically.

One strategy to reduce the potential spurious correlation induced by mismeasurement of Q consists of eliminating the observations that have the most extreme growth in sales or investment. There are two reasons why the mismeasurement problem might be correlated with a firm's growth rate. First, evidence from the accounting literature is consistent with the informational content of earnings differing across companies. In particular, earnings (and correspondingly cash flow) convey more information for young, growing companies, than for large and established ones. (See Collins and Kothari [1989].)

Second, the papers in this literature typically deflate all the variables by the value of capital (net property, plant, and equipment) at the beginning of the fiscal year. This method provides consistent estimates if all variables are recorded at short intervals or if there is no growth. In practice, however, neither of the two assumptions is satisfied. Variables are recorded at annual intervals and companies grow substantially over the sample period - a median of $18 \%$ per year for our sample. If both investment and cash flow grow at a rate similar to the growth rate of sales, then part of the co-movement of investment and cash flow may be due to a scale factor. This effect would bias the estimates of the investment-cash flow sensitivity toward one, particularly in firms with higher annual growth rates.

To account for this possibility, we estimate regressions that eliminate or downweight observations with high growth rates. The first four columns of table 10 report the results of regressions that exclude firm-years with more than $30 \%$ sales growth (the upper quartile). When we eliminate these observations, the median rate of sales growth for the constrained, possibly constrained, and not constrained firms is essentially equal (between $11 \%$ and $12 \%$ ). The 
investment cash-flow sensitivities decline substantially. Nevertheless, the pattern across the three groups of firms remains qualitatively the same, and the difference in sensitivities is still statistically significant. The second four columns of table 10 report qualitatively similar results when we eliminate firm-years in which net property, plant, and equipment more than doubled. ${ }^{13}$ Finally, we obtain qualitatively and statistically similar results (in unreported regressions) when we apply a robust estimation technique that downweights outliers. ${ }^{14}$

These results indicate that FHP's overall finding (across dividend payout classes) are at least partially driven by extreme observations. Eliminating or downweighting the high growth firm-years reduces the estimated investment cash flow sensitivity of the entire low dividend payout sample to between 0.20 and 0.25 . This is effectively identical to the estimate of 0.23 obtained by FHP for their unconstrained, high payout firms. These are the observations for which cash flow is more likely to be correlated with the mismeasurement of $Q$. This, in turn, implies that other studies that sort firms into subsamples with differential outliers in growth rates -- for example, splits on size and dividend payout ratios -- may be biased toward finding a difference in coefficients on cash flow.

In contrast, the high growth firm-years do not explain the cross-sectional results we obtain

\subsection{Euler equation techniques?}

One additional way to address the mismeasurement of $Q$ is to use the Euler equation approach. See Whited (1992), Bond and Meghir (1994), and Hubbard, Kashyap and Whited (1995). This approach directly tests the first order conditions of an intertemporal maximization

${ }^{13}$ Following a suggestion of David Scharfstein, we investigated all the observations where property plant and equipment more than doubled in a single year. In most of these cases the increase in investment appears to have been driven by a sudden surge in both the demand for the firm's product and firm profits.

14 This method, implemented by STATA, performs an initial screening to eliminate gross outliers prior to calculate starting values and then performs, as suggested by $\mathrm{Li}$ (1985), Huber iterations followed by biweight iterations. The results are available upon request. 
problem and, thus, does not require the measurement of $Q$. It is typically implemented by imposing an exogenous constraint on external finance and testing whether that constraint is binding for a particular group of firms.

The Euler equation tests tend to detect the presence of financial constraints in the same type of low dividend firms we study. This is puzzling given our finding that most of the low dividend firms have access to internal or external finance and, therefore, do not face an explicit limit or constraint. Nevertheless, we explore the robustness of our results to the Euler equation tests by following the approach used by Bond and Meghir (1994) who explicitly model the wedge between internal and external finance. Their empirical implementation involves regressing investment on lagged investment and its square, sales, cash flow, and debt squared, and testing whether the coefficient on cash flow is different across firms with different dividend policies. When we implement this approach, we obtain qualitatively identical results to those from our basic specification. Contrary to the results in Bond and Meghir, the firms we identify as least constrained exhibit the highest coefficients.

6.5. The sensitivity does not increase monotonically with financial constraints?

Our results raise serious doubts about the ability of the most widely used splitting criteria to properly distinguish between the informational content of cash flow and its effect in alleviating financial constraints. The question remains whether other more sophisticated splitting criteria can do so. The ability of any such criterion to do so, however, relies upon the assumption - implict in most of the existing empirical literature -- that the investment-cash flow sensitivity increases monotonically with financial constraints.

Although typically ignored, there are at least three reasons why firms that are more constrained might exhibit particularly low sensitivities making the relationship non-monotonic. First, the sensitivities will not be monotonic if (I) our financially constrained firms are, in fact, financially distressed; and (ii) our financially unconstrained firms are, in fact, constrained. Second, an intertemporal model that incorporates a form of precautionary savings can generate such a 
pattern. Finally, a non-monotonic pattern of sensitivities will arise if the costs of modifying planned capital expenditures in response to a cash flow shock are high. In what follows, we explore whether any of these can explain our cross-sectional results.

Before proceeding, however, we should stress that the first of these alternatives has different implications from the other two. If the non-monotonicity is limited to financially distressed firms, it is potentially legitimate to use the investment-cash flow sensitivity as a measure of financial constraints provided that financially distressed firms are eliminated from the sample. In the other two cases, the problem is much more pervasive and, therefore, much more difficult, if not impossible to overcome.

\subsubsection{Financially constrained equals financially distressed?}

It is plausible that financially distressed firms will exhibit low investment-cash flow sensitivities. For example, an insolvent firm might be forced by its creditors to use additional cash flow to repay debt rather than for capital expenditures. This necessarily will reduce the sensitivity of investment to cash flow. This would explain our results if the firms we classify as constrained and possibly constrained are, in fact, financially distressed, and the firms we classify as unconstrained are, in fact, constrained.

Tables 3 and 11 refute this argument. Table 3 presents firm characteristics by firm-year financial status; table 11 presents firm characteristics by overall sample financial status. First, the bottom of table 3 indicates that firms increase their debt, rather than repay it in the years we classify them as possibly, likely, or definitely constrained. Second, although one might argue that the definitely constrained firm-years are distressed (median interest coverage of I.09), table 3 shows that it is probably not the case for the likely constrained firm-years (median interest coverage of 2.84) and definitely not the case for the possibly constrained firm-years (median interest coverage of 4.20 ). Third, table 11 shows that over the entire sample period, firms we classify as possibly constrained are approximately as healthy as firms we classify as never constrained. Finally, it is unreasonable to describe the likely constrained firms as distressed over 
the entire sample period (median interest coverage of 4.84 ), despite the fact that they are less healthy overall than the other two groups. In fact, FHP intended to eliminate distressed firms because they explicitly excluded firms with overall negative real sales growth from their sample

\subsubsection{Intertemporal constraints versus contemporaneous constraints?}

Although it is understood in theory that an intertemporal model can generate nonmonotonic investment-cash flow sensitivities, most empirical implementations have ignored this possibility. According to such a model, when firms that are very constrained generate additional cash flow, they may decide to hoard it for precautionary reasons rather than invest it. When firms are constrained, but have less urgent precautionary needs, they channel most of the additional cash flow to investment. Finally, when firms are totally unconstrained, investment will be unresponsive to additional cash flow.

Gross (1995) presents a model which generates this behavior. His simulations indicate that the investment-cash flow sensitivity will decrease as firms become less constrained except for firms that are the most financially distressed. Because the simulations and sensitivities reflect firmyears, the same firm can be in different circumstances over time with very different sensitivities from year to year.

Although we think that the intertemporal model has some strong positives and should be given more attention in future empirical work, there are several ways in which the intertemporal model is not consistent with our results. First, the intertemporal model implies that completely unconstrained firm-years will show a sensitivity that is close to zero. In contrast, the sensitivity for our least constrained (NFC) firm-years in regression (1) of table 9 is approximately 0.40 . This is difficult to reconcile with the fact that the NFC firm-years appear as healthy financially as the unconstrained firms in FHP which show a low sensitivity.

Second, regression (2) in table 9 indicates that the investment cash flow sensitivities of firms that were likely constrained or constrained in the previous year are essentially zero. This is surprising given that cash flow recovers substantially -- from 0.24 to 0.34 (of beginning of year 
capital) for likely constrained firms and from -0.20 to 0.26 for constrained firms. In other words, firms that were constrained in the previous year are much less constrained in the following year, yet have low investment-cash flow sensitivities.

Finally, our basic results for overall financial constraint status seem at odds with Gross intertemporal model. The intertemporal model implies that the overall sensitivities will be weighted averages of the firm-year sensitivities. The overall sensitivity of the possibly constrained firms, therefore, should roughly equal that of the unconstrained firms because the results in table 5 classify firms as possibly constrained even if those firms were unconstrained over most of the sample period.

\subsubsection{An adjustment-cost explanation}

A final reason why the investment-cash flow sensitivity might be a misleading indicator of financial constraints is that it ignores a firm's cost of modifying planned capital expenditures in response to a cash flow shock. For example, when a firm experiences a cash flow drop and becomes constrained, it may be unable to reduce capital expenditures immediately to the new desired level if adjustment costs are high. For instance, this would be the case for a firm that was in the middle of building a new factory. If the cash flow of that constrained firm then rebounds, the firm will increase investment, but by less than it would have if it had not been forced to continue investing when it was constrained - i.e., completing the factory. This pattern will reduce the measured investment-cash flow sensitivity for constrained firms. Firms that are never constrained will never find themselves in this situation.

Consistent with this explanation, firms invest a median of $236 \%$ of their cash flow in capital expenditures in constrained and likely constrained firm-years; in the following firm-years, the same firms invest a median of $106 \%$. In contrast, in not constrained and likely not constrained firm-years, firms invest a median of $82 \%$ of their cash flow in capital expenditures; in the following year, the same firms invest a median of $84 \%$.

The possibly constrained firm-years, however, are problematic. Possibly constrained 
firm-years fall in between, with firms investing a median of $124 \%$ of their cash flow in capital expenditures; in the following year, the same firms invest a median of $98 \%$. It is difficult to reconcile this pattern with the fact that we find the lowest investment-cash flow sensitivity for firms classified as possibly constrained over the entire period.

Although the last two arguments - that the investment-cash flow sensitivity does not increase monotonically with financial constraints -- do not completely explain our cross-sectional results, they make some progress in doing so. There is no reason to believe that these arguments are specific to our sample. They cast additional doubt, therefore, on the use of the investment-cash flow sensitivity as evidence of financial constraints in any sample.

7. Implications and conclusions.

Our findings have several implications:

First, the results indicate that a greater sensitivity of investment to cash flow does not provide reliable evidence of a larger differential cost between internal and external finance Sorting by dividend payout ratios has the effect of grouping together firms in very different financial positions. ${ }^{15}$ In our low dividend payout sample, we find that it is the least constrained firms that exhibit the highest investment-cash flow sensitivity and drive the differences in sensitivity across groups. The differential sensitivities appear to be partially driven by differences in growth rates across groups. We suspect this problem is particularly acute in those papers that use size or the dividend payout ratio as a sorting criterion. Even controlling for differences in the extent to which cash flow proxies for investment opportunities, our findings cast doubts on the monotonicity of the investment-cash flow sensitivity with financial constraints. Both of these findings, call into question previous work that uses differential sensitivities across groups to

is Jappelli et al. (1995) obtain a similar result for the consumption literature. They use survey data to identify the real financial status of consumers and find that more than $\mathbf{4 0}$ percent of the individuals classified as constrained by sorting on wealth are, in fact, unconstrained. 
identify the presence of financial constraints.

Second, while we think that some combination of the adjustment cost and intertemporal models can explain why our constrained firms have a low investment-cash flow sensitivity, we do not have a complete understanding of why the investment-cash flow sensitivity is so high for our unconstrained firms. Even when we eliminate observations where cash flow is most likely to proxy for investment opportunities, we still find that unconstrained firms have a high sensitivity.

The high investment-cash flow sensitivities appear to be driven by managers choosing to rely primarily on internal cash flow to invest despite the availability of additional low cost funds. The most financially successful and least constrained firms in our sample appear to follow this rule and, therefore, exhibit a high investment-cash flow sensitivity. The key question -- that we cannot answer with certainty - is whether those least constrained firms are unconstrained in an absolute sense. The answer to this question leads to very different interpretations of this result.

If our least constrained firms are, indeed, unconstrained in an absolute sense, their investment / financing policies can be interpreted as the irrational or overly risk averse choices of self-interested managers. They also can be interpreted as the outcome of a behavioral rule in which some firms invest only when they are generating cash. A firm might follow such a rule if its managers are overly thrifty, "depression babies," who will invest only under such favorable circumstances.

Altematively, if the least constrained firms are constrained in some intertemporal sense, then their investment / financing policies can be interpreted as the value maximizing choice of managers based on the potential costs of becoming financially constrained in the future. Note, however, this interpretation implies that some firms that choose conservative financial policies -low debt with high cash balances -- and appear contemporaneously unconstrained are, in fact, at least as constrained as firms that do not. Accepting such a qualification further calls into question those studies that use a priori criteria based on financial policies to identify financially constrained firms.

It seems important that future work attempt to distinguish among these explanations 
because of their disparate policy implications for institutional and incentive design. For example, if the source of self-restraint is the optimal response to the possibility of future constraints, then the constant presence of financial intermediaries that can alleviate future information problems would reduce this sensitivity. Altematively, if the source of self-restraint is excessive risk aversion or a behavioral rule, then the sensitivity can potentially be reduced by changes in management compensation schemes.

Third, independent of which of these explanations hold, our results suggest that policies designed to make credit more available in recessions will not lead to increased investment by firms with the highest investment-cash flow sensitivity. These firms reduce their investment in response to poor cash flow despite the current availability of internal and external funds.

The fourth and final implication of our paper is a methodological one. Our research design and results point out what we think is a weakness in existing research as well as an opportunity for future research. A great deal can be learned through more direct observation. 


\section{References}

Afterman, Allan and Bruce Willis, 1991, Handbook of SEC Accounting and Disclosure, (New York: Warren, Gorham, \& Lamont.)

Bernanke, Benjamin, Mark Gertler, and Simon Gilchrist, forthcoming, "The Financial Accelerator and The Flight to Quality," Review of Economics and Statistics.

Bhattacharya, Sudipto, 1979, "Imperfect information, dividend policy, and 'The bird in the hand' fallacy," Bell Joumal of Economics, Spring, 259-270.

Blanchard, Olivier, Florencio Lopez-de-Silanes, and Andrei Shleifer, 1994, "What Do Firms Do With Cash Windfalls?" Joumal of Financial Economics.

Bond, Stephen and Costas Meghir, 1994, "Dynamic Investment Models and the Firm's Financial Policy," Review of Economic Studies 61, 197-222.

Calomiris, Charles, and Glenn Hubbard, forthcoming, "Internal Finance and Investment: Evidence from the Undistributed Profits Tax of 1936-1937," Journal of Business.

Collins, Daniel and S.P. Kothari, 1989, "An Analysis of Intertemporal and Cross-sectional Determinants of Earnings Response Coefficients," Joumal of Accounting and Economics 11, 143-181.

Diamond, Douglas, 1994, "Corporate Capital Structure: The Control Roles of Bank and Public Debt with Taxes and Costly Bankruptcy," Federal Reserve Bank of Richmond Economic Quarterly.

Fazzari, Steven, R. Glenn Hubbard and Bruce Petersen, 1988, "Financing Constraints and Corporate Investment," Brookings Papers on Economic Activity, 141-195.

Gilchrist, Simon and Charles Himmelberg, 1994, "Evidence for the Role of Cash Flow in Investment," Working paper, Federal Reserve Board of Govemors.

Greenwald, Bruce, Joseph Stiglitz, and Andrew Weiss, 1984, "Information Imperfections and Macroeconomic Fluctuations," American Economic Review.

Gross, David, 1995, "The Investment and Financing Decisions of Liquidity Constrained Firms," Working paper, Massachusetts Institute of Technology.

Grossman, Sanford, and Oliver Hart, 1982, Corporate Financial Structure and Managerial Incentives, in: J.J. McCall, ed., The economics of in formation and uncertainty (University of Chicago Press, Chicago, IL).

Hart, Oliver and John Moore, 1995, "Debt and Seniority: An Analysis of the Role of Hard Claims in Constraining Management," American Economic Review 85, 567-585.

Hart, Oliver, 1993, "Theories of Optimal Capital Structure: A Managerial Discretion Perspective," in M. Blair, ed., The Deal Decade, (Washington DC: The Brookings Institution).

Hayashi, Fumio, 1982, "Tobin's Marginal q and Average q: A Neoclassical Interpretation," Econometrica 50, 213-224.

Hoshi, Takeo, Anil Kashyap, and David Scharfstein, 1991, "Corporate Structure Liquidity and Investment: Evidence from Japanese Panel Data," Quarterly Journal of Economics 106 , 
33-60.

Hubbard, R. Glenn, 1994, "Is There a 'Credit Channel' for Monetary Policy?" National Bureau of Economic Research, Working paper $\# 4977$.

Hubbard, R. Glenn, Anil Kashyap, and Toni Whited, 1995, "Internal Finance and Firm Investment," Journal of Money, Credit and Banking 27.

Jensen, Michael, 1986, "Agency Costs of Free Cash Flow, Corporate Finance and Takeovers," American Economic Review 76, 323-329.

Jensen, Michael and William Meckling, 1976, "The Theory of the Firm: Managerial Behavior, Agency Costs, And Ownership Structure, Journal of Financial Economics 3, 305-360.

Jappelli, Tullio, Jorn-Steffen Pischke, and Nicolas Souleles, 1995, "Testing for liquidity constraints in Euler equations with complementary data sources," working paper, MIT.

Kashyap, Anil, Owen Lamont and Jeremy Stein, 1994, "Credit Conditions and the Cyclical Behavior of Inventories," Quarterly Journal of Economics 109, 565-593.

Kiyotaki, Nobuhiro and John Moore, 1993, “Credit Cycles,” Working paper, London School of Economics.

Lamont, Owen, 1994, "Cash Flow and Investment: Evidence from Internal Capital Markets," Working paper, Princeton University.

Miller, Merton and Kevin Rock, 1985, "Dividend policy under asymmetric information," Journal of Finance 40,1031-1051.

Murray, Ronald, William Decker, and Nelson Dittmar, 1993, The Coopers \& Lybrand SEC Manual, (New Jersey: Prentice Hall).

Myers, Stewart, 1984, “The Capital Structure Puzzle," Journal of Finance 39, 575-592.

Myers, Stewart and Nicholas Majluf, 1984, "Corporate Financing and Investment Decisions when Firms Have Information that Investors Do Not Have," Journal of Financial Economics13, 187-221.

Oliner, S. and Rudebusch G., 1992, "Sources of the Financing Hierarchy for Business Investment," Review of Economics and Statistics, 643-654.

Perfect, Steven and Kenneth Wiles, 1994, "Alternative Constructions of Tobin's q: An Empirical Comparison," Journal of Empirical Finance 1, 313-341.

Poterba, James, 1988, "Comments on Fazzari, Hubbard, and Petersen," Brookings Papers on Economic Activity, 200-204.

Stulz, Rene, 1990, "Managerial Discretion and Capital Structure," Journal of Financial Economics $26,3-28$.

Summers, Lawrence, 1981, "Taxation and Corporate Investment: A Q Theory Approach," Brookings Papers on Economic Activity 1, 67-127.

Whited, Toni, 1992, "Debt, Liquidity Constraints, and Corporate Investment: Evidence from Panel Data," Journal of Finance 47, 1425-1460. 
Apromelis

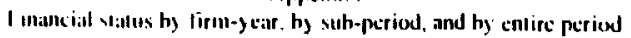

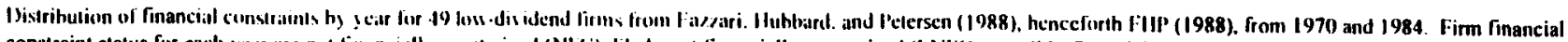

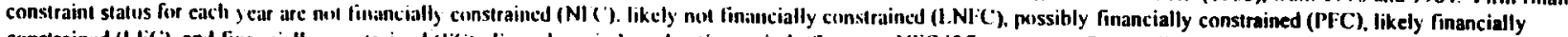

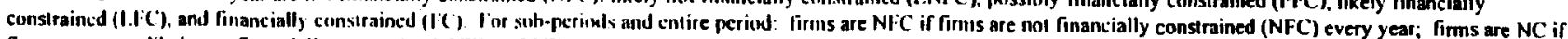

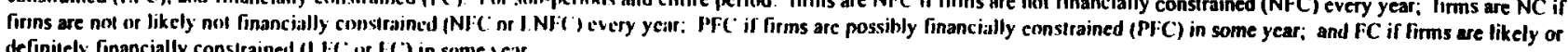
definitely financially constrained (t.t. (ur $(\mathrm{C})$ in some )e:
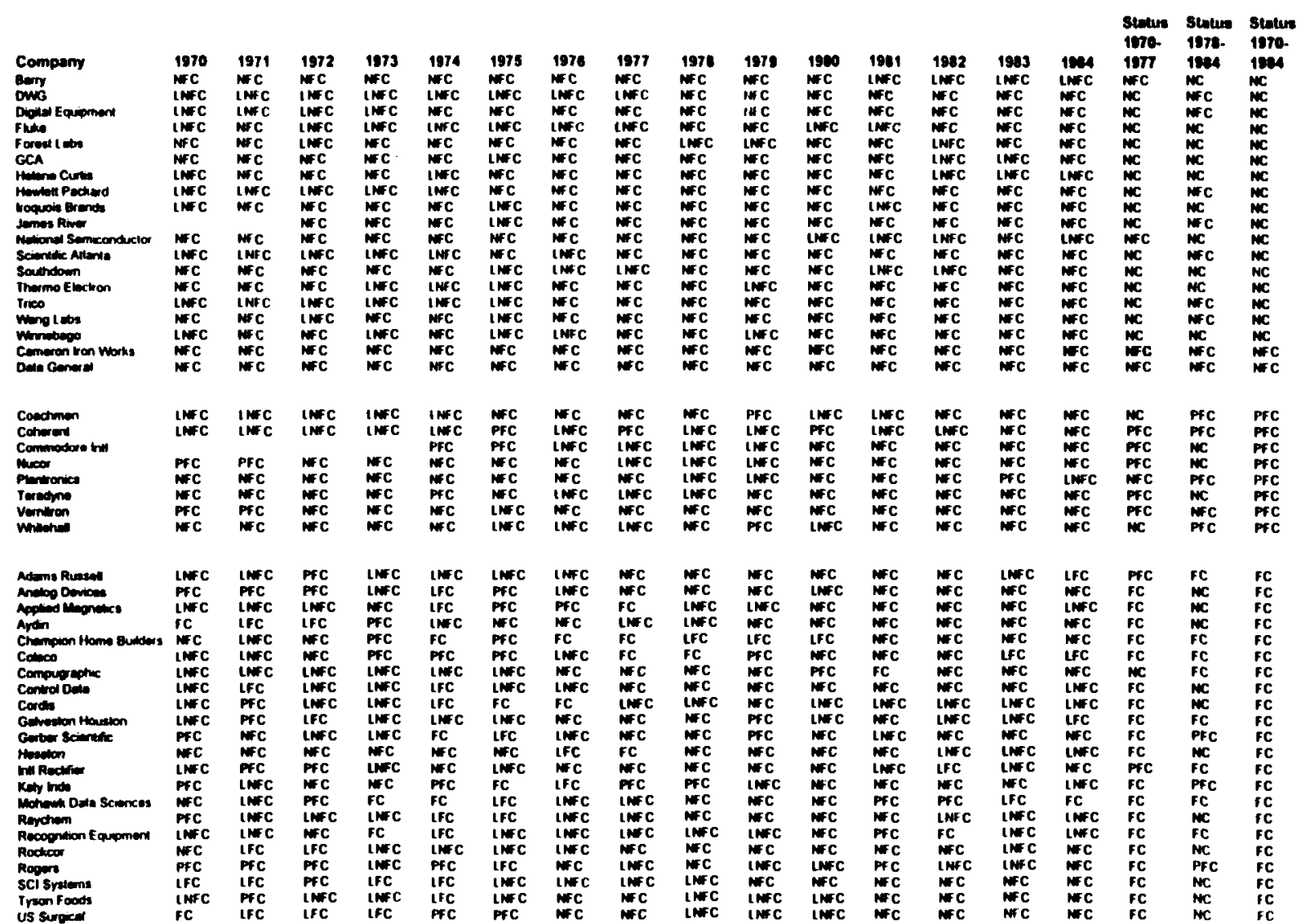
Table I

Comparison of regression of insevtment on cash flow and $Q$ with Fazzari. H lubbard, and Petersen results

Regression of investment un cissh flow ind () for 49 low-dividend firms from Fazzari, Hubbard, and Petersen (1988), henceforth FHP (1988), from 1970 and 1984 compared to estiniales in HIIP III essmem is capital expenditures (COMPUSTAT item 128). Cash flow equals the sum of eamings before extraordinary items (COMPUSTAT iten 18 ) and depreciation (COMPUSTAT item 14). Investment and cash flow are deflated by beginning of year capital ( $K_{1,1}$ ) which we define as net property, plant, and equipment (COMPUSTAT item 8). Q equals the market value of assets divided by the book value of assets (COMPUSTAT item 6). Market value of assets equals the book value of assets plus the market value of common stock less the sum of the book value of common stock

(COMPUSTAT item 6) and baiance sheet deferred taxes (COMPUSTAT item 74). All regressions include firm fixed effects and year effects. Standard errors are in brackets.

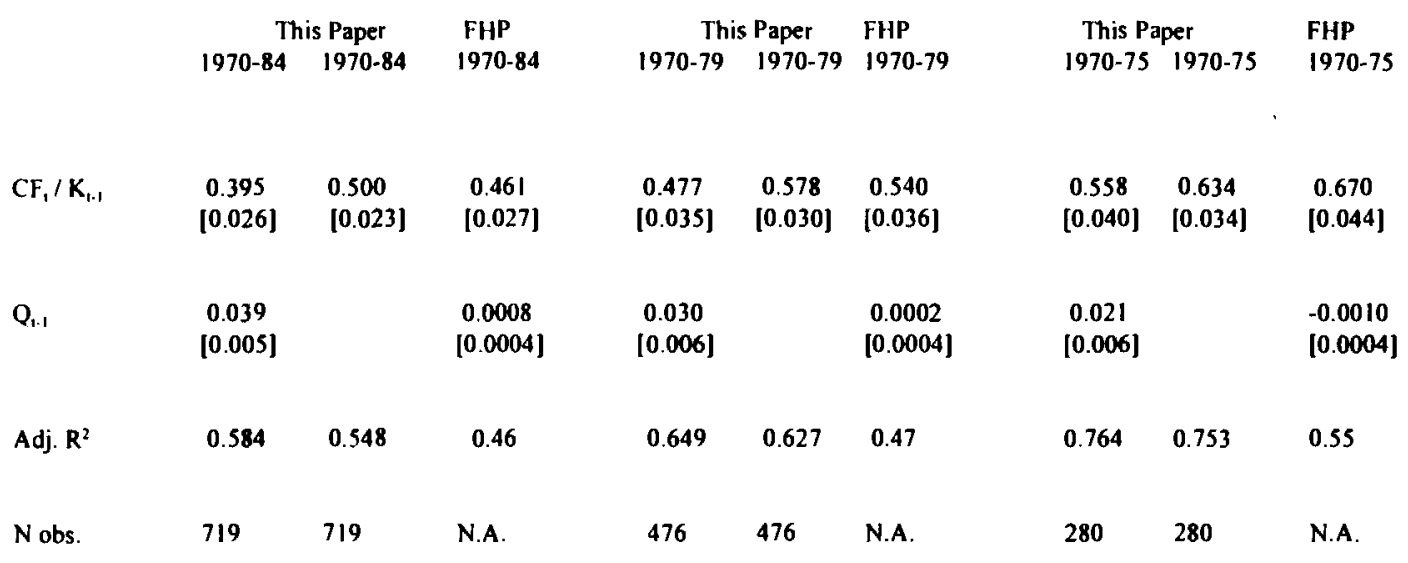


Table 2

Summary of annual financial constraint status

Distribution of financial constraints by year for 49 low-dividend firms from Fazzari, llubbard, and Petersen (1988), henceforth FHP (1988), from 1970 and 1984. Firm financial constraint status for each year are not financially constrained (NFC), likely not financially constrained (LNFC), possibly financially constrained (PFC). likcly linancially constrained (LFC), and financially constrained (FC).

\begin{tabular}{|c|c|c|c|c|c|c|c|}
\hline & NFC & $\begin{array}{l}\text { LNFC } \\
\text { Likely }\end{array}$ & PFC & LFC & FC & $\begin{array}{l}\text { NFC + LNFC } \\
\text { Not }\end{array}$ & $\begin{array}{l}\text { PFC + LFC + FC } \\
\text { Possibly, Likely, }\end{array}$ \\
\hline & & Not & Possibly & Likely & Definitely & or Likely Not & or Definitely \\
\hline & Financially & Financially & Financially & Financially & Financially & Financially & Financially \\
\hline & Constrained & Constrained & Constrained & Constrained & Constrained & Constrained & Constrained \\
\hline 1970 & $34.0 \%$ & $44.7 \%$ & $14.9 \%$ & $2.1 \%$ & $4.3 \%$ & $78.7 \%$ & $21.3 \%$ \\
\hline 1971 & 38.3 & 34.0 & 17.0 & 10.7 & 0.0 & 72.3 & 27.7 \\
\hline 1972 & 43.8 & 35.4 & 12.5 & 8.3 & 0.0 & 79.2 & 20.8 \\
\hline 1973 & 39.6 & 45.8 & 6.3 & 4.2 & 4.2 & 85.4 & 14.6 \\
\hline 1974 & 36.7 & 28.6 & 12.2 & 16.3 & 6.1 & 65.3 & 34.7 \\
\hline 1975 & 30.6 & 42.9 & 14.3 & 8.2 & 4.1 & 73.5 & 26.5 \\
\hline 1976 & 51.0 & 38.8 & 2.0 & 4.1 & 4.1 & 89.8 & 10.2 \\
\hline 1977 & 59.2 & 28.6 & 4.1 & 0.0 & 8.2 & 87.8 & 12.2 \\
\hline 1978 & 67.3 & 26.5 & 2.0 & 2.0 & 2.0 & 93.8 & 6.2 \\
\hline 1979 & 61.2 & 26.5 & 10.2 & 2.0 & 0.0 & 87.8 & 12.2 \\
\hline 1980 & 73.5 & 20.4 & 4.1 & 2.0 & 0.0 & 93.9 & 6.1 \\
\hline 1981 & 71.4 & 20.4 & 6.1 & 0.0 & 2.0 & 91.8 & 8.2 \\
\hline 1982 & 69.4 & 24.5 & 2.0 & 2.0 & 2.0 & 93.9 & 6.1 \\
\hline 1983 & 69.4 & 24.5 & 2.0 & 4.1 & 0.0 & 93.9 & 6.1 \\
\hline 1984 & 69.4 & 22.4 & 0.0 & 6.1 & 2.0 & 91.8 & 8.2 \\
\hline Total & 54.5 & 30.9 & 7.3 & 4.8 & 2.6 & 85.3 & 14.7 \\
\hline
\end{tabular}


Table 3

Summary statistics for firm characteristics by yearly financial constraint stanus

Distribution of financial variables by annual financial constraint status for 49 low-dividend firms from FHP (1988) from 1970 and 1984. Fim financial constraint status for each year are not financially constrained (NFC), likely not finencially constrained (LNFC), possibly financially financial constraint status for each year are not financial y constrained (NFC). Iikely not financial ly constrained (LNFC), possibly financis constrained (PFC), likely financially constrained (LFC), and financially constrained (FC). Each entry reports the median. mean. 10th

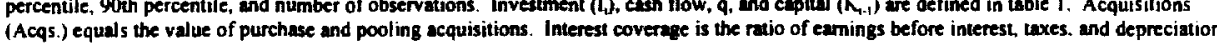
(EBITDA) to interest expense. Debt is the sum of the book value shor-term and long-term debt. Total capital is the sum of debt, the book: value of preferred stock, and the book value of common equity. Free divs. is the tmount of retained earnings that are not restricted from being paid out as dividends. Cash is cash and marketable securities. Unused line, is the amount of unused line of credit at the end of year $t$. Slack is the sum of cash and unused line. Change in debt is the change in the sum of the book value of short-term and long-term debt. Equiry issue is the sum of the equity issued to the public and 10 acquisition targets.

$\begin{array}{llllll}\text { NFC } & \text { LNFC } & \text { PFC } & \text { LFC } & \text { FC } & \text { All } \\ & \text { Likely } & \text { Possibly Likely } & & \text { Firm-Years } \\ \text { Not Fin. } & \text { Not Fin. } & \text { Fin. } & \text { Fin. } & \text { Fin. } & \\ \text { Constr } & \text { Constr. } & \text { Constr. } & \text { Constr. } & \text { Constr. } & \end{array}$

\section{A Inyesiment Cash Flow, Growth}

\begin{tabular}{|c|c|c|c|c|c|c|}
\hline \multirow[t]{5}{*}{ I, $/ \mathbf{L}$} & 0.368 & 0.324 & 0.359 & 0.273 & 0.243 & 0.348 \\
\hline & 0.461 & 0.413 & 0.450 & 0.350 & 0.313 & 0.436 \\
\hline & 0.159 & 0.159 & 0.122 & 0.073 & 0.068 & 0.127 \\
\hline & 0.831 & 0.831 & 0.824 & 0.909 & 0.544 & 0.810 \\
\hline & 393 & 221 & 52 & 34 & 19 & 719 \\
\hline \multirow[t]{5}{*}{ Cash Flow $/ \mathbf{K}_{1.1}$} & 0.506 & 0.350 & 0.313 & 0.243 & 0.020 & 0.421 \\
\hline & 0.614 & 0.435 & 0.366 & 0.191 & -0.047 & 0.505 \\
\hline & 0.209 & 0.104 & -0.125 & -0.126 & -0.436 & 0.122 \\
\hline & 1.075 & 0.871 & 1.084 & 0.528 & 0.366 & 1.007 \\
\hline & 393 & 221 & 52 & 34 & 19 & 719 \\
\hline \multirow[t]{5}{*}{$\left(\right.$ Cash Flow, $\left.-I_{r}\right) / K_{1.1}$} & 0.110 & 0.026 & -0.026 & -0.071 & -0.198 & 0.051 \\
\hline & 0.155 & 0.022 & -0.085 & -0.159 & -0.360 & 0.069 \\
\hline & -0.180 & -0.316 & -0.474 & -0.642 & -0.785 & -0.285 \\
\hline & 0.503 & 0.323 & 0.420 & 0.141 & -0.076 & 0.442 \\
\hline & 393 & 221 & 52 & 34 & 19 & 719 \\
\hline \multirow[t]{5}{*}{$Q$} & 1.313 & 1.171 & 1.159 & 1.096 & 1.082 & 1.231 \\
\hline & 1.647 & 1.542 & 1.312 & 1.527 & 1.402 & 1.580 \\
\hline & 0.809 & 0.755 & 0.793 & 0.734 & 0.799 & 0.785 \\
\hline & 2.781 & 2.799 & 1.934 & 2.659 & 1.789 & 2.749 \\
\hline & 393 & 221 & 52 & 34 & 19 & 719 \\
\hline \multirow{2}{*}{$\begin{array}{l}\text { Fraclion Firms with } \\
\text { Acquisitions in Year, }\end{array}$} & 0.244 & 0.244 & 0.154 & 0.176 & 0.000 & 0.228 \\
\hline & 393 & 221 & 52 & 34 & 19 & 719 \\
\hline \multirow[t]{5}{*}{ Acqs., / K, I } & 0.000 & 0.000 & 0.000 & 0.000 & 0.000 & 0.000 \\
\hline & 0.122 & 0.159 & 0.063 & 0.023 & 0.000 & 0.121 \\
\hline & 0.000 & 0.000 & 0.000 & 0.000 & 0.000 & 0.000 \\
\hline & 0.287 & 0.300 & 0.044 & 0.029 & 0.000 & 0.252 \\
\hline & 388 & 217 & 52 & 34 & 19 & 710 \\
\hline \multirow[t]{5}{*}{ Salen (Irumeli" } & 0.211 & 0.150 & 0.123 & 0.136 & 0.008 & 0.180 \\
\hline & 0.226 & 0.165 & 0.097 & 0.113 & 0.049 & 0.188 \\
\hline & 0.021 & -0.071 & -0.136 & -0.145 & -0.275 & -0.051 \\
\hline & 0.484 & 0.385 & 0.319 & 0.338 & 0.305 & 0.452 \\
\hline & 393 & 221 & 52 & 34 & 19 & 719 \\
\hline \multirow[t]{5}{*}{ Inventin q wholh } & 0199 & 0.117 & 0.144 & 0.063 & -0.064 & 0.154 \\
\hline & 0.215 & 0.160 & 0.135 & 0.049 & .0 .013 & 0.179 \\
\hline & -0.073 & -0.175 & -0.056 & -0.499 & -0.487 & -0.135 \\
\hline & $0 \$ 45$ & 0.475 & 0.376 & 0.562 & 0.543 & 0.512 \\
\hline & 393 & 221 & 52 & 34 & 19 & 719 \\
\hline
\end{tabular}




\begin{tabular}{|c|c|c|c|c|c|c|}
\hline & $\begin{array}{l}\text { NFC } \\
\text { Not Fin. } \\
\text { Constr. }\end{array}$ & $\begin{array}{l}\text { LNFC } \\
\text { Likely } \\
\text { Not Fin. } \\
\text { Constr. }\end{array}$ & $\begin{array}{l}\text { PFC } \\
\text { Possibly Likely } \\
\text { Fin. } \\
\text { Constr. }\end{array}$ & $\begin{array}{l}\text { LFC } \\
\text { Fin. } \\
\text { Constr. }\end{array}$ & $\begin{array}{l}\text { FC } \\
\text { Fin. } \\
\text { Constr. }\end{array}$ & $\begin{array}{l}\text { All } \\
\text { Firm-Year }\end{array}$ \\
\hline B. Financial Policy & & & & & & \\
\hline $\begin{array}{l}\text { Interest } \\
\text { Coverage, }\end{array}$ & $\begin{array}{c}7.971 \\
18.026 \\
2.746 \\
46.722 \\
393\end{array}$ & $\begin{array}{l}5.886 \\
11.777 \\
1.608 \\
23.605 \\
221\end{array}$ & $\begin{array}{l}4.203 \\
4.745 \\
0.000 \\
9.598 \\
52\end{array}$ & $\begin{array}{l}2.836 \\
3.455 \\
0.666 \\
6.960 \\
34\end{array}$ & $\begin{array}{l}1.093 \\
1.650 \\
0.000 \\
3.827 \\
19\end{array}$ & $\begin{array}{l}6.406 \\
14.023 \\
1.707 \\
33.325 \\
719\end{array}$ \\
\hline $\begin{array}{l}\text { Debs, to Total } \\
\text { Capital }\end{array}$ & $\begin{array}{l}0.296 \\
0.293 \\
0.051 \\
0.526 \\
393\end{array}$ & $\begin{array}{l}0.351 \\
0.352 \\
0.117 \\
0.585 \\
221 .\end{array}$ & $\begin{array}{l}0.431 \\
0.454 \\
0.258 \\
0.689 \\
52\end{array}$ & $\begin{array}{l}0.541 \\
0.573 \\
0.316 \\
0.791 \\
34\end{array}$ & $\begin{array}{l}0.565 \\
0.621 \\
0.361 \\
0.912 \\
19\end{array}$ & $\begin{array}{l}0.349 \\
0.344 \\
0.075 \\
0.585 \\
719\end{array}$ \\
\hline Dividends, / $\mathbf{k}$ & $\begin{array}{l}0.000 \\
0.015 \\
0.000 \\
0.046 \\
393\end{array}$ & $\begin{array}{l}0.000 \\
0.006 \\
0.000 \\
0.023 \\
221\end{array}$ & $\begin{array}{l}0.000 \\
0.006 \\
0.000 \\
0.028 \\
52\end{array}$ & $\begin{array}{l}0.000 \\
0.002 \\
0.000 \\
0.028 \\
34\end{array}$ & $\begin{array}{l}0.000 \\
0.001 \\
0.000 \\
0.007 \\
19\end{array}$ & $\begin{array}{c}0.000 \\
0.011 \\
0.000 \\
0.037 \\
719\end{array}$ \\
\hline $\begin{array}{l}\text { Fraction of Years } \\
\text { Dividends Restricted }\end{array}$ & $\begin{array}{l}0.061 \\
393\end{array}$ & $\begin{array}{l}0.276 \\
221\end{array}$ & $\begin{array}{l}0.462 \\
52\end{array}$ & $\begin{array}{l}0.686 \\
34\end{array}$ & $\begin{array}{l}0.789 \\
19\end{array}$ & $\begin{array}{l}0.206 \\
719\end{array}$ \\
\hline Free Divs., / $\boldsymbol{K}_{\text {.1 }}$ & $\begin{array}{l}0.208 \\
0.334 \\
0.004 \\
0.740 \\
247\end{array}$ & $\begin{array}{l}0.013 \\
0.139 \\
0.000 \\
0.430 \\
129\end{array}$ & $\begin{array}{l}0.000 \\
0.043 \\
0.000 \\
0.078 \\
34\end{array}$ & $\begin{array}{l}0.000 \\
0.019 \\
0.000 \\
0.089 \\
29\end{array}$ & $\begin{array}{l}0.000 \\
0.000 \\
0.000 \\
0.000 \\
15\end{array}$ & $\begin{array}{l}0.101 \\
0.229 \\
0.000 \\
0.634 \\
454\end{array}$ \\
\hline Cash, $/ K_{t-1}$ & $\begin{array}{l}0.331 \\
0.726 \\
0.050 \\
1.276 \\
393\end{array}$ & $\begin{array}{l}0.150 \\
0.253 \\
0.034 \\
0.596 \\
221\end{array}$ & $\begin{array}{l}0.150 \\
0.263 \\
0.041 \\
0.721 \\
52\end{array}$ & $\begin{array}{l}0.077 \\
0.156 \\
0.029 \\
0.389 \\
34\end{array}$ & $\begin{array}{l}0.085 \\
0.139 \\
0.016 \\
0.292 \\
19\end{array}$ & $\begin{array}{l}0.168 \\
0.364 \\
0.033 \\
0.784 \\
719\end{array}$ \\
\hline Unused Line, $>0$ & $\begin{array}{l}0.723 \\
393\end{array}$ & $\begin{array}{l}0.652 \\
221\end{array}$ & $\begin{array}{l}0.654 \\
52\end{array}$ & $\begin{array}{l}0.529 \\
34\end{array}$ & $\begin{array}{l}0.579 \\
19\end{array}$ & $\begin{array}{l}0.683 \\
719\end{array}$ \\
\hline $\begin{array}{l}\text { Unused Line, } \\
K_{1},\end{array}$ & $\begin{array}{l}0.270 \\
0.523 \\
0.000 \\
1.097 \\
393\end{array}$ & $\begin{array}{l}0.178 \\
0.313 \\
0.000 \\
0.733 \\
221\end{array}$ & $\begin{array}{l}0.136 \\
0.291 \\
0.000 \\
0.900 \\
52\end{array}$ & $\begin{array}{l}0.043 \\
0.151 \\
0.000 \\
0.449 \\
34\end{array}$ & $\begin{array}{l}0.072 \\
0.159 \\
0.000 \\
0.900 \\
19\end{array}$ & $\begin{array}{l}0.203 \\
0.415 \\
0.000 \\
0.979 \\
719\end{array}$ \\
\hline Slach, $\mathbf{K}$ & $\begin{array}{l}0.725 \\
1.249 \\
0.217 \\
2.039 \\
393\end{array}$ & $\begin{array}{l}0.420 \\
0.566 \\
0.118 \\
1.129 \\
221\end{array}$ & $\begin{array}{l}0.344 \\
0.449 \\
0.059 \\
0.923 \\
52\end{array}$ & $\begin{array}{l}0.211 \\
0.374 \\
0.044 \\
0.721 \\
34\end{array}$ & $\begin{array}{l}0.229 \\
0.320 \\
0.001 \\
1.065 \\
19\end{array}$ & $\begin{array}{l}0.557 \\
0.919 \\
0.126 \\
1.679 \\
719\end{array}$ \\
\hline Ch I I b h $h$. & $\begin{array}{c}0.048 \\
0.168 \\
-0.304 \\
0.718 \\
393\end{array}$ & $\begin{array}{c}0.048 \\
0.157 \\
-0.354 \\
0.760 \\
221\end{array}$ & $\begin{array}{c}0.153 \\
0.405 \\
-0.470 \\
0.983 \\
52\end{array}$ & $\begin{array}{c}0.272 \\
0.473 \\
-0.414 \\
1.581 \\
34\end{array}$ & $\begin{array}{l}0.017 \\
0.012 \\
-0.546 \\
0.974 \\
19\end{array}$ & $\begin{array}{c}0.062 \\
0.191 \\
-0.354 \\
0.797 \\
719\end{array}$ \\
\hline Equity Issue, / $\mathbf{K}_{1-1}$ & $\begin{array}{l}0.000 \\
0.224 \\
0.000 \\
0.634 \\
373\end{array}$ & $\begin{array}{l}0.000 \\
0.149 \\
0.00 \\
0.419 \\
193\end{array}$ & $\begin{array}{l}0.000 \\
0.042 \\
0.00 \\
0.044 \\
38\end{array}$ & $\begin{array}{l}0.000 \\
0.020 \\
0.000 \\
0.000 \\
31\end{array}$ & $\begin{array}{l}0.000 \\
0.046 \\
0.000 \\
0.256 \\
16\end{array}$ & $\begin{array}{l}0.000 \\
0.177 \\
0.000 \\
0.455 \\
651\end{array}$ \\
\hline
\end{tabular}


Table 4

Ordered logits for predictability of financial constraint status

Ordered logits for the determination of annual financial constraint status for 49 low-dividend firms from FHP (1988) from 1970 and 1984. Financial constraint status for each year is ordered from not financially constrained (NFC), likely not financially constrained (LNFC), possibly financially constrained (PFC), likely financially constrained (LFC), to financially constrained (FC). Variable definitions are in tables 1 and 3 . Standard enrors are in brackets.

Dependent Variable is Financial Constraint Status

\begin{tabular}{|c|c|c|c|c|}
\hline Cash flow $/ K_{1.1}$ & $\begin{array}{l}-0.886 \\
{[0.230]}\end{array}$ & $\begin{array}{l}-1.164 \\
{[0.256]}\end{array}$ & $\begin{array}{l}-0.688 \\
{[0.222]}\end{array}$ & $\begin{array}{l}-0.839 \\
{[0.235]}\end{array}$ \\
\hline$Q_{\mathbf{t}}$ & $\begin{array}{c}0.276 \\
{[0.080]}\end{array}$ & $\begin{array}{c}0.370 \\
{[0.087]}\end{array}$ & & \\
\hline Debt / Total Capital & $\begin{array}{c}2.071 \\
{[0.470]}\end{array}$ & $\begin{array}{c}2.251 \\
{[0.480]}\end{array}$ & $\begin{array}{c}1.825 \\
{[0.464]}\end{array}$ & $\begin{array}{c}1.938 \\
{[0.471]}\end{array}$ \\
\hline Dividends, / $K_{1-1}$ & $\begin{array}{r}-23.039 \\
{[5.949]}\end{array}$ & $\begin{array}{r}-21.787 \\
{[6.134]}\end{array}$ & $\begin{array}{l}-22.551 \\
{[5.905]}\end{array}$ & $\begin{array}{l}-20.409 \\
{[6.043]}\end{array}$ \\
\hline Dividends Restricted $(Y=1, N=0)$ & $\begin{array}{c}1.496 \\
{[0.213]}\end{array}$ & $\begin{array}{c}1.365 \\
{[0.224]}\end{array}$ & $\begin{array}{c}1.472 \\
{[0.213]}\end{array}$ & $\begin{array}{c}1.294 \\
{[0.222]}\end{array}$ \\
\hline Unrestricted Ret. Eamings / $\mathrm{K}_{1-1}$ & $\begin{array}{l}-1.897 \\
{[0.497]}\end{array}$ & $\begin{array}{l}-1.936 \\
{[0.513]}\end{array}$ & $\begin{array}{l}-1.896 \\
{[0.499]}\end{array}$ & $\begin{array}{l}-1.956 \\
{[0.513]}\end{array}$ \\
\hline $\mathrm{Cash}_{1} / \mathrm{K}_{\mathrm{t}-1}$ & $\begin{array}{l}-1.704 \\
{[0.311]}\end{array}$ & $\begin{array}{l}-1.590 \\
{[0.323]}\end{array}$ & $\begin{array}{l}-1.675 \\
{[0.311]}\end{array}$ & $\begin{array}{l}-1.567 \\
{[0.320]}\end{array}$ \\
\hline Unused line of credit $>0$ & $\begin{array}{l}-0.711 \\
{[0.176]}\end{array}$ & $\begin{array}{l}-0.547 \\
{[0.207]}\end{array}$ & $\begin{array}{l}-0.758 \\
{[0.175]}\end{array}$ & $\begin{array}{l}-0.511 \\
{[0.206]}\end{array}$ \\
\hline cut 1 & $\begin{array}{l}-0.252 \\
{[0.312]}\end{array}$ & $\begin{array}{c}0.608 \\
{[0.480]}\end{array}$ & $\begin{array}{l}-0.693 \\
{[0.285]}\end{array}$ & $\begin{array}{c}0.119 \\
{[0.462]}\end{array}$ \\
\hline _cut2 & $\begin{array}{c}1.973 \\
{[0.328]}\end{array}$ & $\begin{array}{c}2.928 \\
{[0.499]}\end{array}$ & $\begin{array}{c}1.510 \\
{[0.298]}\end{array}$ & $\begin{array}{c}2.413 \\
{[0.478]}\end{array}$ \\
\hline _cut3 & $\begin{array}{c}2.987 \\
{[0.353]}\end{array}$ & $\begin{array}{c}3.988 \\
{[0.518]}\end{array}$ & $\begin{array}{c}2.501 \\
{[0.320]}\end{array}$ & $\begin{array}{c}3.433 \\
{[0.494]}\end{array}$ \\
\hline _cuta & $\begin{array}{c}4.307 \\
{[0.413]}\end{array}$ & $\begin{array}{c}5.353 \\
{[0.562]}\end{array}$ & $\begin{array}{c}3.790 \\
{[0.378]}\end{array}$ & $\begin{array}{c}4.736 \\
{[0.532]}\end{array}$ \\
\hline Year dummies & No & Yes & No & Yes \\
\hline Log Likelihood & -645.0 & -627.0 & -650.6 & -635.7 \\
\hline Pseudo- $\mathrm{R}^{\text {: }}$ & 0.201 & 0.223 & 0.194 & 0.213 \\
\hline
\end{tabular}


Table 5

Regression of investment on cash flow and $Q$ by financially constrained status over entire sample period

Regression of investment on cash flow and $Q$ for 49 low-dividend firms from FHP (1988) from 1970 and 1984. Variables are defined in table I. Regressions are estimated for total sample and by financially constrained status where 19 firms are never financially constrained over the entire period (NFC or LNFC in every year), 8 firms are possibly financially constrained at some time (PFC in some year), and 22 firms are likely financially constrained at some time in the period (LFC or FC). Overall status is based on firm financial constraint status for each year of not financially constrained (NFC), likely nor financially

constrained (LNFC), possibly financially constrained (PFC), likely financially constrained (LFC), and financially constrained (FC). All regressions include firm fixed effects and year effects. Standard errors are in brackets.

\begin{tabular}{|c|c|c|c|c|c|c|}
\hline & $\begin{array}{l}\text { All } \\
\text { Firms } \\
N=49\end{array}$ & $\begin{array}{l}\text { Firms } \\
\text { Never } \\
\text { Constrained } \\
\mathrm{N}=19\end{array}$ & $\begin{array}{l}\text { Firms } \\
\text { Possibly } \\
\text { Constrained } \\
\mathrm{N}=8\end{array}$ & $\begin{array}{l}\text { Firms } \\
\text { Likely } \\
\text { Constrained } \\
\mathrm{N}=22\end{array}$ & $\begin{array}{l}\text { Firms } \\
\text { Never / Possibly } \\
\text { Constrained } \\
\mathrm{N}=27\end{array}$ & $\begin{array}{l}\text { Firms } \\
\text { Possibly / Likely } \\
\text { Constrained } \\
\mathrm{N}=30\end{array}$ \\
\hline$C F_{1} / K_{1,4}$ & $\begin{array}{c}0.395 \\
{[0.026]}\end{array}$ & $\begin{array}{c}0.702 \\
{[0.041]}\end{array}$ & $\begin{array}{c}0.180 \\
{[0.060]}\end{array}$ & $\begin{array}{c}0.340 \\
{[0.042]}\end{array}$ & $\begin{array}{c}0.439 \\
{[0.035]}\end{array}$ & $\begin{array}{c}0.250 \\
{[0.032]}\end{array}$ \\
\hline $\mathbf{Q}_{t .1}$ & $\begin{array}{c}0.039 \\
{[0.005]}\end{array}$ & $\begin{array}{c}0.009 \\
{[0.006]}\end{array}$ & $\begin{array}{c}0.016 \\
{[0.049]}\end{array}$ & $\begin{array}{c}0.070 \\
{[0.018]}\end{array}$ & $\begin{array}{c}0.033 \\
{[0.006]}\end{array}$ & $\begin{array}{c}0.059 \\
{[0.017]}\end{array}$ \\
\hline Adj. $R^{2}$ & 0.584 & 0.793 & 0.240 & 0.410 & 0.655 & 0.358 \\
\hline N obs. & 719 & 279 & 113 & 327 & 392 & 440 \\
\hline
\end{tabular}


Tahle 6

Regression of investment on cashl flow and $Q$ by financially constrained status in two sub-periods treating firn-sub-periods as different firms

Regression of ims estment on cash flow and $Q$ for 49 low-dividend firms from FHP (1988) from 1970 and 1984. Variables are defined in table 1. Sample is divided into two suh-periods. 1970-1977 and 1978-1984. Firm financial constraint status is determined within each sub-period. 57 firm-sub-periods are never financially constrained (NFC or I.NFC every year), 14 firm-sub-periods are possibly financially constrained (PFC in some year), 27 firm-sub-periods are likely financially constrained (LFC or FC in some year), and 15 firm-sub-periods are NFC every year. Overall sub-period status is based on firm financial constraint status for each year of not financially constrained (NFC), likely not financially constrained (LNFC), possibly financially constrained (PFC), likely financially constrained (LFC), and financially constrained (FC). Regressions include firm fixed effects for each sub-period, resulting in up to 98 firm-period fixed effects, and year effects. Standard errors are in brackets.

\begin{tabular}{|c|c|c|c|c|c|c|c|}
\hline & $\begin{array}{l}\text { All } \\
\text { Firms } \\
N=98\end{array}$ & $\begin{array}{l}\text { Firms } \\
\text { Never } \\
\text { Constrained } \\
\mathrm{N}=57\end{array}$ & $\begin{array}{l}\text { Firms } \\
\text { Possibly } \\
\text { Constrained } \\
N=14\end{array}$ & $\begin{array}{l}\text { Firms } \\
\text { Likely } \\
\text { Constrained } \\
\mathrm{N}=27\end{array}$ & $\begin{array}{l}\text { Firms } \\
\text { Never / Possibly } \\
\text { Constrained } \\
\mathrm{N}=71\end{array}$ & $\begin{array}{l}\text { Firms } \\
\text { Possibly / Likely } \\
\text { Constrained } \\
\mathrm{N}=4 \text { I }\end{array}$ & $\begin{array}{l}\text { Firms } \\
\text { NFC } \\
\text { Every Year } \\
N=15\end{array}$ \\
\hline$C F_{1} / K_{1,1}$ & $\begin{array}{c}0.436 \\
{[0.028]}\end{array}$ & $\begin{array}{c}0.680 \\
{[0.041]}\end{array}$ & $\begin{array}{c}0.259 \\
{[0.067]}\end{array}$ & $\begin{array}{c}0.274 \\
{[0.050]}\end{array}$ & $\begin{array}{c}0.523 \\
{[0.034]}\end{array}$ & $\begin{array}{c}0.262 \\
{[0.037]}\end{array}$ & $\begin{array}{c}0.779 \\
{[0.084]}\end{array}$ \\
\hline$Q_{t .1}$ & $\begin{array}{c}0.033 \\
{[0.005]}\end{array}$ & $\begin{array}{c}0.010 \\
{[0.006]}\end{array}$ & $\begin{array}{c}0.081 \\
{[0.059]}\end{array}$ & $\begin{array}{c}0.048 \\
{[0.023]}\end{array}$ & $\begin{array}{c}0.025 \\
{[0.006]}\end{array}$ & $\begin{array}{c}0.054 \\
{[0.021]}\end{array}$ & $\begin{array}{c}0.002 \\
{[0.009]}\end{array}$ \\
\hline Adj. $R^{2}$ & 0.604 & 0.721 & 0.402 & 0.391 & 0.661 & 0.402 & 0.837 \\
\hline $\mathrm{N}$ obs. & 719 & 416 & 98 & 205 & 514 & 303 & 110 \\
\hline
\end{tabular}


Table 7

Regression of investment on cash llow and $Q$ by fimanciaily constrained status over 1970-1977 and 1978-1984

Regression of investment on eitsh flow and $Q$ for 49 low-dividend firms from FHP (1988) from 1970 and 1984 . Variables are defined in table $I$. Sample is divided into two subperiods, 1970-1977 and 1978-1984. Firm financial constraint status is determined within each sub-period. 57 firm-sub-periods are never financially constrained (NFC or LNFC every year). 14 firm-suh-puriods are possibly financially constrained (PFC in some year), 27 firm-sub-periods are likely financially constrained (LFC or FC in some year), and 15 firm-sub-periods are NFC every year. Overall sub-period status is based on firm financial constraint status for each year of not financially constrained (NFC). likely not financially constrained (I NIC C) possibly financially constrained (PFC), likely financially constrained (LFC), and financially constrained (FC) Regressions include firm fixed effects for each sut-period Standard errors are in brackets.

\begin{tabular}{|c|c|c|c|c|c|c|c|}
\hline & $\begin{array}{l}\text { All } \\
\text { Firms } \\
N=49\end{array}$ & $\begin{array}{l}\text { Firms } \\
\text { Never } \\
\text { Constrained } \\
\mathrm{N}=23\end{array}$ & $\begin{array}{l}\text { Firms } \\
\text { Possibly } \\
\text { Constrained } \\
\mathrm{N}=7\end{array}$ & $\begin{array}{l}\text { Firms } \\
\text { Likely } \\
\text { Constrained } \\
N=19\end{array}$ & $\begin{array}{l}\text { Hirms } \\
\text { Never / Possibly } \\
\text { Constrained } \\
\mathrm{N}=\mathbf{3 0}\end{array}$ & $\begin{array}{l}\text { Firms } \\
\text { Possibly / I.ikely } \\
\text { Constrained } \\
N=19\end{array}$ & $\begin{array}{l}\text { Firms } \\
\text { NFC } \\
\text { Every Year } \\
N=5\end{array}$ \\
\hline$C F_{1} / K_{11}$ & $\begin{array}{c}0505 \\
{[0.037]}\end{array}$ & $\begin{array}{l}0.746 \\
{[0.051 \mid}\end{array}$ & $\begin{array}{c}0.247 \\
{[0.086]}\end{array}$ & $\begin{array}{c}0.364 \\
{[0.069]}\end{array}$ & $\begin{array}{c}0.553 \\
{[0.045]}\end{array}$ & $\begin{array}{c}0.306 \\
{[0.049]}\end{array}$ & $\begin{array}{c}0.783 \\
\{0.142\}\end{array}$ \\
\hline Q.1. & $\begin{array}{c}0.035 \\
00.017\}\end{array}$ & $\begin{array}{c}0.006 \\
|10007|\end{array}$ & $\begin{array}{c}0.027 \\
{[0.082]}\end{array}$ & $\begin{array}{c}0.025 \\
{[0.023]}\end{array}$ & $\begin{array}{c}0.023 \\
{[0.007]}\end{array}$ & $\begin{array}{c}0.029 \\
{[0.022]}\end{array}$ & $\begin{array}{c}0.002 \\
{[0.015]}\end{array}$ \\
\hline Adj. $R^{2}$ & 0.696 & 0.827 & 0.381 & 0.454 & 0.755 & 0.446 & 0.832 \\
\hline \multirow[t]{2}{*}{ N obs. } & 378 & 179 & 50 & 149 & 229 & 199 & 40 \\
\hline & $\begin{array}{l}\text { All } \\
\text { Firms } \\
N=49\end{array}$ & $\begin{array}{l}\text { Firms } \\
\text { Never } \\
\text { Constrained } \\
\mathrm{N}=34\end{array}$ & $\begin{array}{l}\text { Firms } \\
\text { Possibly } \\
\text { Constrained } \\
N=7\end{array}$ & $\begin{array}{l}\text { Fims } \\
\text { Likely } \\
\text { Constrained } \\
\mathrm{N}=8\end{array}$ & $\begin{array}{l}\text { Firms } \\
\text { Never / Possibly } \\
\text { Constrained } \\
\mathrm{N}=41\end{array}$ & $\begin{array}{l}\text { Firms } \\
\text { Possibly / Likely } \\
\text { Constrained } \\
N=15\end{array}$ & $\begin{array}{l}\text { Firms } \\
\text { NFC } \\
\text { Every Year } \\
N=10\end{array}$ \\
\hline $\mathrm{CF}_{1} / \mathrm{K}_{\mathrm{t} \cdot 1}$ & $\begin{array}{c}0.326 \\
{[0.044]}\end{array}$ & $\begin{array}{c}0.571 \\
{[0.069]}\end{array}$ & $\begin{array}{c}0.272 \\
{[0.152]}\end{array}$ & $\begin{array}{c}0.141 \\
{[0.061]}\end{array}$ & $\begin{array}{c}0.470 \\
{[0.058]}\end{array}$ & $\begin{array}{c}0.160 \\
{[0.053\}}\end{array}$ & $\begin{array}{c}0.800 \\
{[0.126]}\end{array}$ \\
\hline$Q_{1}$ & $\begin{array}{c}0.054 \\
{[0.026]}\end{array}$ & $\begin{array}{l}-0.019 \\
{[0.028]}\end{array}$ & $\begin{array}{c}0.154 \\
{[0.088 \mid}\end{array}$ & $\begin{array}{c}0.413 \\
{[0.084]}\end{array}$ & $\begin{array}{c}0.007 \\
{[0.027]}\end{array}$ & $\begin{array}{c}0.272 \\
{[0.073]}\end{array}$ & $\begin{array}{l}-0.054 \\
{[0.047]}\end{array}$ \\
\hline $\mathbf{R}^{2}$ & 0.392 & 0.467 & 0.422 & 0.459 & 0.439 & 0.402 & 0.703 \\
\hline N obs. & 341 & 237 & 48 & 56 & 285 & 104 & 70 \\
\hline
\end{tabular}


Table 8

Regression of in esiment on cash how and $Q$ by other measure of financially constrained status over entire sample period and entire sub-period

Regression of investment on cash flow and $Q$ for 49 low-dividend firms from FHP (1988) from 1970 and 1984 . Variables are defined in tables 1 and 3. Regressions (1) - (3) are estinuated for total sample and by (i) whether firms ever had interest coverage below 2.5; and (ii) firms that are not explicitly restricted from paying dividends over the entire sample period. Interest coverage is the ratio of EBITDA to interest expense. Regressions (4) - (6) are estimated using firm financial status over sample sub-periods 1970-1977 and 1978-1984. Regressions (1) - (3) include firm fixed effects and year effects. Regressions (4) - (6) include firm fixed effects for each sub-period, resulting in up to 98 firm-period fixed effects, and year effects. Standard errors are in brackets.

$\begin{array}{ll}\text { (1) } & \text { (2) } \\ \text { All } & \text { Firms that } \\ \text { Firms } & \begin{array}{l}\text { never have } \\ \text { coverage below }\end{array} \\ & \begin{array}{l}2.5 \text { from 1970-1984 } \\ \mathrm{N}=49\end{array} \\ & \mathrm{~N}=13\end{array}$

\begin{tabular}{|c|c|c|c|c|c|c|}
\hline$C F_{1} / K_{1,1}$ & $\begin{array}{c}0.395 \\
{[0.026]}\end{array}$ & $\begin{array}{c}0.673 \\
{[0.056]}\end{array}$ & $\begin{array}{c}0.435 \\
{[0.042]}\end{array}$ & $\begin{array}{c}0.436 \\
{[0.028]}\end{array}$ & $\begin{array}{c}0.801 \\
{[0.062]}\end{array}$ & $\begin{array}{c}0.499 \\
{[0.038]}\end{array}$ \\
\hline$Q_{1.1}$ & $\begin{array}{c}0.039 \\
{[0.005]}\end{array}$ & $\begin{array}{c}0.011] \\
\{0.008\}\end{array}$ & $\begin{array}{c}0.035 \\
{[0.007]}\end{array}$ & $\begin{array}{c}0.033 \\
{[0.005]}\end{array}$ & $\begin{array}{l}-0.003 \\
{[0.008]}\end{array}$ & $\begin{array}{c}0.027 \\
{[0.006]}\end{array}$ \\
\hline Adj. $R^{2}$ & 0.584 & 0.756 & 0.674 & 0.604 & 0.772 & 0.715 \\
\hline N obs. & 719 & 191 & 247 & 719 & 189 & 402 \\
\hline
\end{tabular}


Regression of investment on cash flow, Q, and cash flow interacted with financially constrained status, restricted dividend status, and low cash and unused line of credit status for 49 low-dividend firms from FIIP (1988) from 1970 and 1984. Variables are delined in tables $I$ and 3 . Firm financial constraint status for each year are not financially

constrained (NFC), likely not linancially constrained (LNFC), possibly financially constrained (PFC), likely financially constrained (LFC), and financially constrained (FC). The non-interacted cash flow variable represents years in which firms are not financially constrained. Regression (1) uses financial constraint status at the end of the fiscal year; (2) uses financial constraint status at the beginning of the fiscal year. Regression (3) interacts cash flow with a dummy variable that equats one if a firm's covenants restrict it from paying dividends. Regression (4) interacts cash flow with a dummy variable that equals one if a firm's slack is in the lowest quartile of firm-years (less than 0.28 of net property. plant, and equipment). Slack is the sum of cash and unused line of credit. Regressions include firm fixed effects. Standard errors are in brackets.

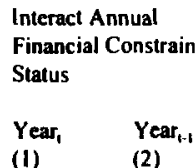

$0.389-0.407$

$[0.029] \quad[0.029]$

$\mathrm{CF}_{\mathrm{s}} / \mathrm{K}_{\mathrm{r}, \mathrm{I}}$

$\times F_{i} / K_{1 .}$

$-0.027 \quad-0.239$

$x$ PFC $\quad[0.060] \quad[0.056]$

$\mathrm{CF}_{1} / \mathrm{K}_{1-1}-0.183-0.382$

$x$ LFC $\quad[0.115] \quad[0.086]$

$\begin{array}{ll}\mathbf{- 0 . 2 6 1} & -0.39\end{array}$

$\times F_{1} / K_{4}$

Adj. $\mathbf{R}^{2}$

Nobs.

\section{Interact Annual}

Restricted Dividend Status

(3)

$\mathrm{CF}_{1} / \mathrm{K}_{\mathbf{1}-1}$

$\mathrm{CF}_{\mathrm{t}} / \mathrm{K}_{\mathrm{r}-\mathrm{s}}$

X Restricted

Dividends
0.414

[0.027]

[0.051]

[0.005]

0.586

719
Interact Annual

Low Slack

Status

$\mathrm{CF}_{1} / \mathrm{K}_{\mathrm{I}, 1} \quad \mathbf{0 . 4 1 0}$

$\mathrm{CF}_{1} / \mathrm{K}_{\mathrm{H}, 3} \quad \mathbf{0 . 0 9 4}$

$x$ Low Slack 
Table 10

Regression of investment on cash flow and $Q$ by financially constrained status over entire period eliminating observations with high sales or investment growth.

Regression of investment on cash flow and $Q$ for 49 low-dividend firms from FHP (1988) from 1970 and 1984 . Variables are defined in table $\mathrm{I}$. Regressions are estimated for total sample and by financially constrained status where 19 firms are never financially constrained over the entire period (NFC or LNFC in every year), 8 firms are possibly financially constrained at some time ( $\mathrm{PFC}$ in some year), and 22 firms are likely financially constrained at some time in the period (LFC or FC). Overall status is based on firm financial constraint status for each year of not financially constrained (NFC), likely not financially

constrained (LNFC), possibly financially constrained (PFC), likety financially constrained (LFC), and financially constrained (FC). All regressions include firm fixed effects and year effects. Standard errors are in brackets.

\section{No fim-years with more than $30 \%$ sales prowth}

All Firms

$\begin{array}{ll}\text { Firms } & \text { Firms } \\ & \text { Never }\end{array}$

Constrain

$\mathrm{N}=19$

Possibly

Constrained Constrained

$\mathrm{N}=8 \quad \mathrm{~N}=\mathbf{2 2}$

$C F_{1} / K_{1-1}$

\subsection{6}

0.531

[0.124]

0.104

[0.045]

0.233

[0.058]

$Q_{\text {1.1 }}$

$\begin{array}{ll}0.051 & 0.033\end{array}$

0.048

[0.012] [0.014]

[0.053]

0.049

[0.024]

Adj. $\mathbf{R}^{2}$

$\begin{array}{ll}0.328 & 0.502\end{array}$

Nobs.

535

201

0.270

255
No firm-years with investment exceedine initial capital $\left(K_{-11}\right)$

$\begin{array}{cccc}\begin{array}{l}\text { All } \\ \text { Firms }\end{array} & \begin{array}{l}\text { Firms } \\ \text { Never } \\ \text { Constrained } \\ \mathrm{N}=19\end{array} & \begin{array}{l}\text { Firms } \\ \text { Possibly } \\ \text { Constrained } \\ \mathrm{N}=8\end{array} & \begin{array}{l}\text { Firms } \\ \text { Likely } \\ \text { Constrained } \\ \mathrm{N}=22\end{array} \\ 0.203 & 0.366 & \begin{array}{l}0.149 \\ {[0.046]}\end{array} & \begin{array}{c}0.211 \\ {[0.032]}\end{array} \\ {[0.031]} & {[0.042]} & & \\ 0.046 & 0.023 & -0.00] & 0.067 \\ {[0.009]} & {[0.010]} & {[0.027]} & {[0.013]} \\ & & & \\ 0.449 & 0.597 & 0.252 & 0.427 \\ 679 & 263 & 109 & 307\end{array}$


Table 11

Median firm characteristics by financially constrained status in entire sample period.

Median firm characteristics by overall financial constraint status for 49 low-dividend firms from FHP (1988) from 1970 and 1984. Overall status is based on firm financial constraint status for each year of not financially constrained (NFC), likely not financially constrained (LNFC), possibly financially constrained (PFC), likely financially constrained (LFC), and financially constrained (FC). For the entire period, 19 firms are never financially constrained over the entire period (NFC or LNFC in every year), 8 firms are possibly financially constrained at some time (PFC in some year). and 22 firms are likely financially constrained at some time in the period ( $L F C$ or $F C$ ). Each entry reports the median and number of observations. Investment ( $I_{V}$, cash flow, $q$, and capital $\left(\mathrm{K}_{\mathrm{t}, \mathrm{l}}\right)$ are defined in table $\mathrm{l}$. Interest coverage is the ratio of earnings before interest, taxes, and depreciation (EBITDA) to interest expense. Debt is the sum of the book value short-term and long-term debt. Total capital is the sum of debt, the book value of preferred stock, and the book value of common equity. Free divs. is the amount of retained earnings that are not restricted from being paid out as dividends. Cash is cash and marketable securities. Unused line, is the amount of unused line of credit at the end of year $t$. Slack is the sum of cash and unused line.

$\begin{array}{llll}\text { Never } & \text { Possibly } & \text { Likely } & \text { All } \\ \text { Constrained } & \text { Constrained } & \text { Constrained } & \text { Firm-Years } \\ N=279 & N=113 & N=327 & N=719\end{array}$

A. Inveriment. Cash Flow, Growth

$\mathbf{l}, / \mathbf{K}$

$\begin{array}{llll}0.348 & 0.403 & 0.337 & 0.348 \\ 0.451 & 0.517 & 0.364 & 0.421 \\ 0.081 & 0.142 & 0.001 & 0.051 \\ 1.262 & 1.438 & 1.200 & 1.231 \\ 0.194 & 0.176 & 0.172 & 0.180\end{array}$

Sales Growth

0.194

8.070

9.928

4.842

6.406

Interest Coverage,

0.289

0.249

0.415

0.349

Fraction of Years

Dividends Restricted

0.115

0.070

0.327

0.206

Free Divs. $/ K_{\text {, }}$

0.186

0.315

0.023

0.101

Cash, / K.

0.215

0.239

0.109

0.168

linused Line, $>0$

0.631

0.649

0.730

0.683

Unused Line $/ \mathrm{K}$

0.153

0.208

0.256 